\title{
TAX TREATMENT OF THE FAMILY: THE CANADIAN ROYAL COMMISSION ON TAXATION AND THE INTERNAL REVENUE CODE
}

\author{
It would indeed appear that nobody loves a bachelor! \\ Professor Harold M. Groves ${ }^{1}$
}

In September, 1962, the Canadian government appointed a Royal Commission on Taxation vested with a broad mandate to

inquire into and report upon the incidence and effects of taxation imposed by Parliament . . . upon the operation of the national economy, the conduct of business, the organization of industry and the positions of individuals; and to make recommendations for improvements in the tax laws and their administration that may be consistent with the maintenance of a sufficient flow of revenue. ${ }^{2}$

More than seven hundred witnesses and three hundred briefs later, ${ }^{3}$ the Commission in December, 1966, submitted its Report: six volumes (nearly 2700 pages) of proposals for sweeping revision of the Canadian federal tax system. ${ }^{4}$

The Report appears destined for considerable controversy as well as acclaim. One commentator observes:

1 H. Groves, Federal Tax Treatment of the Family 28 (1963) [hereinafter cited as Groves].

2 Order in Council P.C. 1962-1334. Named to the Commission were Kenneth LeM. Carter, chairman, J. Harvey Perry, A. Emile Beauvais, Donald G. Grant, Eleanor Milne and Charles E. S. Walls.

31 Report of the Royal Commission on Taxatron xiii (limited ed. 1966) [hereinafter cited as REPORT].

4 Volume 1 includes an introduction, acknowledgments and minority reports; volume 2 treats the use of the tax system to achieve economic and social objectives; volumes 3 and 4 are devoted to the taxation of income; volume 5 covers sales taxes and tax administration; and volume 6 encompasses implications of the various proposals made in the other volumes.

In regard to the current status of the Commission's proposals, Canadian Finance Minister Sharp is reported to have stated that no legislation embodying the major proposals would be presented to Parliament "for some time." Report of the Canadian Royal Commission on Taxation, 16 OrL \& GAS Q. 179, 180 (1967).

For the rather sketchy commentary appearing to date on the REPORT, see id.; Canadian Tax Foundation, Report of Proceedings of the 19Th Tax Conference (1967) [hereinafter cited as Canadian TAX Foundation]; Barbeau, The Report: "The Premise Dictates the Conclusion", 10 CAN. B.J. 153 (1967) ; Goodman, Royal Commission Would Tax as Income Gifts and Inheritance of Canadians, $26 \mathrm{~J}$. TAXATION 370 (1967); Vineberg, Royal Commission Proposals Would Revolutionize Canadian Tax System, 26 J. TAXation 258 (1967). 
The Report is likely to evoke awe and admiration for its imaginative scope and depth and, at the same time, intensive criticism and debate on some of its omnivorous accounting and taxing proclivities. ${ }^{5}$

Another has called the Report "stern, uncompromising, ungenerous, tight-fisted and mean." 6 More broadly, the Report has been deemed "an ideological manifesto designed to promote a new social order in Canada . . . as much a political as a fiscal compendium." 7

While the Report is a unified document, many of its features can be closely examined on their own. Among its more notable proposals are the following: a "comprehensive tax base" 8 to include gifts and bequests, inter alia, as ordinary income; elimination of estate and gift taxation of donors; taxation of capital gains at ordinary income tax rates; reduction of progressive income tax rates to a maximum of fifty per cent; and integration of personal and corporate income taxes, entailing a fifty per cent tax at the corporate level, coupled, upon distribution of income by the corporation, with a tax refund to the shareholder based on the difference, if any, between his tax rate and the corporate rate.

One of the Commission's most provocative and timely recommendations is for adoption of a "family unit" (together with an individual unit) for purposes of (1) measuring income and reporting and paying income taxes, (2) allocating the income tax burden and (3) attaching tax consequences to transfers of property (including cash) within and between tax units. The proposed family unit has been heralded as a "much-needed step in the development of the equitable income tax." 9

This Comment consists of three parts. The Commission's family unit is discussed first. ${ }^{10}$ Next, the Internal Revenue Code's treatment of the family is outlined. Finally, the Commission's family unit is evaluated with reference to the goals of a tax system and in light of the shortcomings in the Internal Revenue Code.

5 Vineberg, supra note 4, at 261.

B Remarks of F. D. Gibson, in Canadian Tax Foundation 271.

7 Barbeau, supra note 4, at 153.

8 For recent treatment of the notion of a "comprehensive tax base," see the series of articles, Bittker, $A$ "Comprehensive Tax Base" as a Goal of Income Tax Reform, 80 HARv. L. REv. 925 (1967); Musgrave, In Defense of an Income Concept, 81 Harv. L. REv. 44 (1967) ; Pechman, Comprehensive Income Taxation: A Comnent, id. at 63; Bittker, Comprehensive Income Taxation: $A$ Response, id. at 1032 (1968); Galvin, More on Boris Bittker and the Comprehensive Tax Base: The Practicalities of Tax Reform and the $A B A$ 's CSTR, id. at 1016.

o Remarks of Joseph A. Pechman, in Canadian Tax Foundatyon 443.

10 It should be stressed that the Commission's family unit, like most of the Commission's proposals, cannot be fully understood except in the context of the entire Report. Limitations of space prevent full discussion here. 


\section{The Royal Commission's Family Unit}

\section{Structure}

The proposed family unit encompasses five groupings: ${ }^{11}$

(1) a husband and wife, and any dependent children; ${ }^{12}$

(2) a surviving spouse, and any dependent children; ${ }^{13}$

(3) a divorced or separated parent and one or more dependent children;

(4) one or more dependent children who have been in a family unit but who are separated from both parents by reason of the parents' death or residence outside Canada; and

(5) an individual and one or more dependent children, in the cases of adoption and unwed mothers. ${ }^{14}$

Dependent children are defined as unmarried children, resident in Canada, natural-born or adopted, and under 22 years of age. ${ }^{15}$ In addition, two options are available. To account for self-sufficiency at an early age, a child under 22 employed full-time and not living with his parents can withdraw from the family unit at his or his parents' option. To account for the full-time university student, a student 22 to 25 years of age can remain a member of the family unit if both he and his parents so desire. ${ }^{16}$ Actual support is irrelevant for purposes of inclusion or exclusion. ${ }^{17}$

Although other persons, such as an elderiy parent, are sometimes dependent in fact upon, and may be an integral part of, the proposed family unit, they are excluded from that unit ${ }^{18}$ and comprise an

113 REPORT 132-33.

12 Common-law marriages qualify so long as the couple have cohabited for one year and file a joint declaration that they wish to be treated as husband and wife for tax purposes. Id. at 142. For the definition of dependent children, see text accompanying note 15 infra.

13 For rate purposes a surviving spouse without dependent children is treated as an individual; however, he or she is deemed to still be in the original family unit so that transfers of property by the deceased spouse's estate to the surviving spouse constitute intrafamily transfers and hence entail no tax consequences. Id. at 151 n.16. Intrafamily transfers are discussed in text accompanying notes 49-60 infra.

14 Possible tax units other than the Commission's family unit include the individual unit (which the Commission recommends for taxpayers not in a family unit), the marital unit (husband and wife only), the broad family unit (all relatives living together) and the household unit (all persons living together).

153 REPORT 133. Id. at $151 \mathrm{n} .17$, suggests that arguably the age should be 18 . Mentally or physically "infirm" children of any age are also considered dependent. Id. at 133 .

$16 I d$. at 133.

17 Id. at 134 .

18 Id. at 141. 
individual unit. The supporting unit is allowed a tax credit of ten per cent of all expenditures (up to $\$ 1000$ ) made in support of a "close relative," defined as children who are no longer members of the family unit, a parent of either spouse, aunts, and uncles. ${ }^{19}$

In the usual case, the family unit commences at marriage; it also commences when an unwed mother retains custody of her child, when a single person adopts a child, or when a divorced or separated spouse retains custody of one or more dependents. In the last situation, the original family unit in effect continues without the other spouse, who is in yet another family unit if he or she also retains a dependent. The first tax year for the family unit is the calendar year of its creation. $^{20}$

The income of all the unit's members is aggregated. Income is broadly defined by the Commission to include almost all flows of property into the unit-gifts, bequests, and earnings ${ }^{21}$-as well as previously unrecognized appreciation on property transferred outside the unit, whether by sale, gift or bequest. ${ }^{22}$ Transfers of property within a unit give rise to no tax consequences. ${ }^{23}$ Joint and several liability of husband and wife, in the usual case, is computed with the family rate schedule. ${ }^{24}$ Husband and wife can at their option file separately, in which case any income of their children must be aggregated with that of a parent. ${ }^{25}$ However, separate returns almost invariably entail a higher total tax liability for the family since each spouse's individual liability is computed by doubling his taxable income, applying the family unit's rate schedule, and halving the amount due on that income. ${ }^{26}$

The family unit terminates upon: ${ }^{27}$

(1) the death of the last of the unit's members;

$18 \mathrm{Id}$. at 228-29. Complete dependency is not a condition for the credit. Provision of room and board in the donor's home is deemed to be worth $\$ 1000$. The recipient, meanwhile, is required to report the support assistance as income to the extent it exceeds his $\$ 250$ annual and $\$ 5000$ lifetime gift exemption. In view of these exemptions and relatively low tax rates, the Commission foresees little or no income tax liability for the recipient of such support gifts.

$20 I d$. at 126, 134.

21 Transfers for value and loans, inter alia, do not in themselves give rise to income. For the Commission's discussion of its "comprehensive tax base," see id. at 39-116.

22 Id. at 51.

23 For a discussion of transfers within the unit, see notes 49-60 infra and accompanying text.

243 RePorr 134-35. A dependent child is liable for the tax attributable to any amount of the total reported income for which he is responsible. Id. Only his earned income in excess of $\$ 500$ and his gifts in excess of a $\$ 100$ annual exemption must be reported by the family. Id. at 135,138 .

$25 I d$. at $126,134,189$. Presumably the parents can divide the children between them as they wish.

${ }^{26} I d$. at 189 . The higher total liability is attributable to the progressivity of tax rates and results unless husband and wife separately report equal taxable incomes. See recommended rates, $i d$. at 179, table 11-9.

27 Id. at $128-30,139-40$. 
(2) the non-residence of the last of the unit's members;

(3) the remarriage of a surviving spouse, with or without dependent children;

(4) divorce or legal separation; or

(5) the coming of age of the last dependent child in a family where the parents are no longer in the family unit.

\section{Allocation of the Income Tax Burden}

In its proposed allocation of the income tax burden among various tax units, the Commission relies on the standard of "ability to pay." Taxation in accord with "ability to pay" is "achieved when taxes [are] allocated in proportion to the discretionary economic power of tax units." 28 "Discretionary economic power" is the product of the tax unit's total economic power (defined as the unit's power to command goods and services for personal use) and the fraction of that power available for "discretionary use" by the unit, that is, which does not have to be exercised to maintain the members of the unit ("maintenance" is defined as "the appropriate standard of living ... relative to others"). ${ }^{29}$ The Commission provides this illustration. Assume tax units $A$ and $B$. $A$ has an income of $\$ 10,000$, one-tenth of which can be spent at $A$ 's discretion. $B$ has an income of $\$ 20,000$, two-tenths of which is available for the discretionary use of $B$. Then, in accord with the "ability to pay" principle, the relative taxes on units $A$ and $B$ should be:

$$
\begin{aligned}
\frac{\text { Tax on } A}{\text { Tax on } B} & =\frac{\text { Income of } A \times A^{\prime} \text { 's discretionary use }}{\text { Income of } B \times{ }^{\text {Fraction available for }}} \\
& =\frac{10,000 \times .10}{20,000 \times .20}=\frac{1000}{4000}=\mathrm{I} / 4
\end{aligned}
$$

To raise $\$ 1000$ in tax revenues, for instance, a uniform rate of 20 per cent would be imposed on the discretionary income of each unit. $A$ would pay $\$ 200$, or 20 per cent of its "discretionary economic power" of $\$ 1000$, and $B$ would pay $\$ 800$, or 20 per cent of its $\$ 4000 .^{30}$ The Commission does recognize, however, that "discretionary economic

$28 I d$. at 5.

29 Id. No specific explication is given of the "appropriate standard" except to indicate that it is more than "bare subsistence." The "others" are not defined.

30 Id. at 6-7. 
power" is not an "objective phenomenon," and proceeds to set forth three central factors to be considered in ascertaining fractions of a unit's income available for discretionary use: family responsibilities, income, and certain non-discretionary expenditures. ${ }^{31}$

To recognize differing family responsibilities, the Commission distinguishes unattached individuals, married couples without dependent children, and couples with varying numbers of dependent children. An individual has fewer non-discretionary maintenance expenses than a married couple with the same total income and thus should pay higher taxes. And while "two cannot live as cheaply as one," there are economies to marriage and thus as a rule when two people with the same income marry they should pay more tax than the sum of their taxes before marriage. ${ }^{32}$ Dependent children reduce "discretionary economic power," though in smaller amounts for each successive child. ${ }^{33}$

The Commission argues that "[a]t the bottom of the income scale there are often diseconomies to marriage," 34 notably because after marrying the parties generally can no longer share living accommodations with more than one person and, in order to establish a household, must make expenditures that are greater than the possible savings on other expenses. Consequently, there should not be an increase in total taxes at low income levels after marriage takes place. Conversely, at very high income levels

marital status has relatively little effect on discretionary economic power. When two wealthy individuals marry, their total tax should be greater than the sum of the taxes they paid as single individuals to take into account the economies of living together, but these economies are small when compared to their income. The increase in tax upon marriage for such people should consequently be relatively smaller than for individuals with less income who marry. ${ }^{35}$

Finally, the Commission argues that account should be taken of "non-discretionary" gifts to close relatives to provide them with support, $^{36}$ special expenses of working mothers with young children, and extraordinary medical expenses. ${ }^{37}$

To implement these goals the Commission recommends separate rate schedules for individuals and married couples. Use of a single

31 Id. at 7-8.

32 Id. at $14,142-43$.

33 Id. at 17.

34 Id. at 15.

35 Id. at 15-16.

36 See note 19 supra and accompanying text.

373 REPORT 19. 
schedule with either an exemption or a credit to differentiate individuals from couples is rejected. The exemption is rejected because

To use one schedule for both kinds of units and a fixed [dollar] exemption for the couple would be tantamount to the acceptance of the assumption that the extra nondiscretionary expenses of a couple not only increase with income but increase at the same rate as the marginal rates of tax increase with income. This we cannot accept. We believe that when the level of income is substantial, the fraction of additional income for discretionary use is the same for the couple as for the unattached individual. Adoption of an exemption would give an unwarranted tax reduction to upper income couples and would not be sufficiently generous for low income couples. ${ }^{38}$

As to credits,

The adoption of a credit to differentiate the tax on couples and unattached individuals would pose exactly the opposite problem. This would be tantamount to the acceptance of the assumption that the extra non-discretionary expenses of the couple do not increase with income. If $a$ substantial credit were provided, this would be too generous for low income couples and not sufficiently generous for middle and upper income couples. ${ }^{39}$

Thus the Commission recommends as a middle ground between exemptions and credits the use of separate rate schedules to allow for a more precise and equitable adjustment. ${ }^{40}$

The Commission does, however, reject the extension of separate rate schedules to distinguish among various kinds of family units, specifically those with different numbers of dependent children. The Commission argues that because of the various combinations that would be needed such schedules are not administratively feasible and that, their "refined technique" notwithstanding, such schedules "would introduce complexities for taxpayers that would not be justified by the relatively small amounts involved." ${ }^{41}$ The Commission rejects use of exemptions

38 Id. at 16 (emphasis supplied). The Commission refers to a fixed dollar exemption, not to a percentage exemption. The former is exemplified by the $\$ 600$ personal exemption deduction allowed by INT. REv. CoDE of 1954, §151. The tax savings attendant upon the exemption are basically a function of the taxpayer's marginal rate of tax. A fixed percentage exemption, meanwhile, is exemplified by a constant percentage of income. Its value also rises with the taxpayer's marginal rate, but is sharply accelerated by the fact that its amount as well as the marginal rate on that amount increase with income.

39 Id. at 16-17 (emphasis added). A credit, it will be remembered, is a fixed reduction of the tax liability, and by the Commission's definition does not vary with the taxpayer's income.

40 Id. at 17.

41 Id. 
on the ground that actual expenses for children, while probably increasing with income, do not rise as rapidly as the marginal rates of tax increase with income. Instead, credits are recommended:

Credits against tax are simpler than separate rate schedules and the inherent bias of fixed credits would be in favour of low income families as we think it should be. ${ }^{42}$

The credits are $\$ 100$ for the first child and $\$ 60$ for each additional child. ${ }^{43}$ The Commission acknowledges that these credits

are low in relation to the non-discretionary expenses of raising children. However, to adopt larger credits would reduce revenues and necessitate higher marginal rates with their unfavourable effects on incentives. ${ }^{44}$

In recognition of the additional non-discretionary expenses incurred when both parents work, a family unit in which both husband and wife work for more than 120 days a year is entitled to an $\$ 80$ credit if there is also a child in the unit; an additional $\$ 120$ credit is granted if the child is under seven. ${ }^{45}$ As discussed above, expenditures to support a "close relative" give rise to a credit of up to $\$ 100$, based on 10 per cent of the support expenditures. ${ }^{46}$ Finally, a credit "equal to a substantial proportion (preferably 50 per cent-the top marginal rate) of the medical expenses in excess of a percentage of income" is available to the family unit, as well as to the individual unit. ${ }^{47}$ Again, credits were chosen to make these adjustments because they are less complicated than schedules, less costly than exemptions, and provide a disproportionately greater reduction of "the tax burden on low income families whose ability to pay is most affected by the additional non-discretionary expenses . . ." 48

\section{Tax Consequences of Transfers Within and Without the Family Unit}

Property held by members of a newly formed family unit is usually not included in the income of the new unit. ${ }^{49}$ Only where commence-

$42 I d$.

43 Id. at 181. This means the following average credits per child for various families: one child- $\$ 100$; two children $-\$ 80$; three $-\$ 73$; four $-\$ 70$; five- $\$ 68$; six $-\$ 67$. Id.

44 Id. at 18.

45 Id. at 193.

46 See note 19 supra and accompanying text.

473 REPORT 214 . The Commission suggests that the expenses be required to exceed an unspecified minimum percentage of income before the credit becomes available. Medical credits in general are apparently considered by the Commission an "interim solution" pending some form of complete medical insurance coverage. Id.

48 Id. at $179-80$.

49 Id. at 126,134 . This rule applies to family units formed by marriage of two nondependent children, by an unwed mother retaining custody of her child, by a single person adopting a child, and by a divorced or separated spouse retaining custody of one or more dependents. 
ment of the family unit coincides with a dependent child leaving his original family unit is such property income to the new unit. ${ }^{50}$ This exception is designed to preclude circumvention of the proposed treatment of withdrawal by a child from his family unit, which requires that property taken by the child constitute income to his new unit. ${ }^{51}$ Thus, dependent children do not avoid the tax consequences of withdrawal by marriage.

Transfers of property within a family unit involve no tax consequences:

It is not that [such] transfers . . . would be exempt from tax; it is simply that these transfers would be removed from the purview of the tax system. ${ }^{52}$

Title can thus be transferred within the unit, be it by sale, gift or bequest, with no tax consequences; there is no income or gain to be reported and the property's basis remains unchanged. ${ }^{53}$ One exception is made to this rule. Until a couple has a natural-born child or until the marriage lasts for five years, tax-free transfers to the other spouse can be made only in an amount up to one-half of the income reported by the unit. Any transfers (other than for fair consideration) in excess of this amount constitute income to the family unit. The Commission believes this exception necessary "to reduce tax avoidance through artificially arranged marriages" designed to take advantage of the tax immunity of transfers. ${ }^{54}$

With two exceptions here relevant, flows of income (broadly defined by the "comprehensive tax base" ${ }^{55}$ ) into and between tax units are recognized. ${ }^{56}$ The relevant exceptions are for gifts to and earnings of a dependent child, which are eligible for deposit in a government-administered, interest-bearing "Income Adjustment Account" in the year of receipt. Amounts so deposited are deducted from income. Income is recognized when the deposit is withdrawn, which may be no later than the child's withdrawal from the unit. These

$50 \mathrm{Id}$. at 138. This rule applies as well, of course, to an individual unit so commenced.

51 See text accompanying note 58 infra.

523 REPORT 125.

53 Trusts qualify for this treatment where the beneficiary is a member of the settlor's family unit. See 4 REPORT 160.

543 REPORT 127.

55 See id. at 39-116.

56 Two non-recognition provisions not directly relevant here are for gifts in kind (the tax on which can be spread over a period of 5 to 10 years) and for amounts deposited in a government-administered, non-interest bearing "Income Adjustment Account." (Amounts so deposited do not give rise to taxable income until withdrawn by the depositor; this Account provision must be distinguished from the dependent child's Account, treated immediately following in the text above.) 3 REPORT 269, 503-04. 
exceptions are defended on the ground that such amounts do not increase the "discretionary economic power" of the unit. The gift exemption is thought necessary to avoid a double tax on large gifts to a dependent child from outside the unit, which would otherwise be taxed first to the family and then to the child upon his withdrawal from the unit. For a similar reason the child's employment or business income in excess of a proposed $\$ 500$ exemption is eligible for deposit. ${ }^{57}$

A member is deemed to have withdrawn from the family unit in a number of circumstances, notably when a child ceases to qualify as a dependent (by coming of age, marrying or opting out) and when a member dies or becomes a non-resident. Two tax consequences follow: first, previously unrecognized appreciation of property taken by the withdrawing member constitutes income to the family unit in the year of withdrawal; and second, the withdrawing member includes in the income of his new unit the fair market value of the property taken in excess of his $\$ 5000$ lifetime and $\$ 250$ annual gift and bequest exemptions. ${ }^{58}$ The exemptions are thought sufficient to ensure that most new units commenced by the child's withdrawal are free of tax upon formation. ${ }^{59}$

A family unit terminates in one of two basically different ways. First, if the unit ends by the death or non-residence of the last of the unit's members or by the remaining member(s) coming of age, there is (1) income to the unit in the amount of previously unrecognized appreciation of property which thereby passes from the unit and (2) income to the recipient unit (be it another family unit or an individual one), if any. In other circumstances, no tax consequences attend termination. This results on the remarriage of a surviving spouse (with or without children), on divorce or legal separation, and on the marriage of an unwed person with a dependent child. ${ }^{60}$

\section{Policy Objectives}

As outlined above, the family unit constitutes a single tax unit for three purposes: measuring income and paying income tax, allocating the income tax burden among various units, and attaching tax consequences to transfers of property within and between units.

57 Id. at $135-36$.

$58 \mathrm{Id}$. at 137-38. The $\$ 5000$ lifetime exemption does not accrue until an individual ceases to be a dependent. Id. In the case of withdrawal by death, property taken from the unit is that property bequeathed to persons outside the decedent's family unit. In the cases of death and non-residence, the withdrawing member does not form or become part of a new unit.

$59 \mathrm{Id}$. at 137-38. A dependent child is thus free of income tax on account of property taken into his new unit upon withdrawal (i.e., property he receives from his earlier deposits, if any, in the Account, plus any other property he may possess on leaving the family) to the extent the fair market value of such property does not exceed $\$ 5250$. Amounts in trusts created by a member of the family and of which he is beneficiary are included in the property deemed taken. $4 \mathrm{REPORT} 175$. The general income averaging provisions are also available. See 3 REPORT 138, 276-80.

603 RepoRT 128-30, 139-41. 
For these purposes, the Commission's choice of the family unit ${ }^{61}$ proceeds from its assertion that a tax system should reflect "the basic economic and financial entity" in society. ${ }^{62}$ The Commission argues that upon marriage a couple "adopts the economic concept of the family as the income unit" and that it is "the continued income and financial position of the family which is ordinarily of primary concern, not the income and financial position of the individual members." ${ }^{3}$ Husband and wife thus act as a unit. As the family grows by the addition of children, the family continues to pool its resources and make decisions and expenditures on a group basis. ${ }^{64}$ As a corollary of this unity, the Commission regards taxation of transfers of property between members of a family as "wrong in principle" and gift and death taxes on these transfers as anachronistic. ${ }^{65}$

Then as children come of age, marry, opt out or leave Canada, they are viewed as forming their own economic units and ceasing to be members of their original families. Any other person, even if in fact a full, functioning member of the family in social and economic terms, is excluded from the family unit. The Commission argues that it would "unduly complicate the family unit concept" to allow such persons to become members of the family unit for tax purposes "because it would require elaborate provisions to prevent tax-free transfers between generations."

Intertwined with the social and economic justification for the family unit is the overriding objective of the entire Report: equity, both horizontal and vertical. The Commission defines horizontal equity as individuals and families in similar circumstances bearing the same taxes, vertical equity as those in different circumstances bearing appropriately different taxes. ${ }^{67}$

On the horizontal level, the individual unit is depicted by the Commission as inequitable in two respects. First, the total tax liability of a family whose members are taxed as individuals can vary between two families with the same total income depending on the distribution of income among the members of the respective families: due to the progressivity of income tax rates, the more even the distribution of income within a family the less its tax liability. ${ }^{68}$ Second,

61 Canada presently employs only the individual unit for income tax purposes, with no aggregation except indirectly through a $\$ 1000$ deduction allowed a husband for his wife (reduced by the amount of her income in excess of $\$ 250$ ) and a deduction $(\$ 300$ or $\$ 550$ ) for a dependent child whose income does not exceed $\$ 950$. Id. at 117, 180. Gift and death taxes are presently applicable, inter alia, to transfers between members of a family. 1 REPORT $18-19$.

623 REPORT 124.

63 Id. at 123.

64 Id. at 123-24. The Commission acknowledges that a child's income may have only an indirect bearing on the family income. Id.

651 REPORT 18-19.

663 REPORT 228.

671 REPORT 4-5.

683 RePORT 118, 143. 
the individual unit allows for income splitting (here meaning the deflection of income, whether or not the transaction giving rise to the deflection is motivated by tax minimization) between members of the family, ${ }^{69}$ as by the transfer of income-producing property, by family trusts and partnerships, and so forth. ${ }^{70}$ For the Commission, different distributions of income and income splitting within families should not give rise to different tax liabilities. ${ }^{71}$

In vertical as well as horizontal terms, the Commission believes that only by treating families as entities can their "discretionary economic power" be satisfactorily measured. In turn, it is only through proper income measurement that family units can be equitably compared with individual units and with one another for purposes of equitable allocation of the tax burden.

A third major concern of the Commission is that of enforcement and administration, principally with respect to income tax. At present the Canadian federal tax system contains complex, stringent provisions designed to nullify the income tax effects of family income splitting. ${ }^{2}$ Witnesses before the Commission termed these provisions "inconsistent and discriminatory as between taxpayers" (thereby a departure from horizontal equity) and "too rigid and restrictive in dealing with relationships between spouses." 73 For example, a salary paid to a wife by her husband may be deductible to the husband's business if the business is incorporated, but not otherwise. ${ }^{74}$ Implementation of the family unit would, the Commission hopes, allow for the repeal of the provisions against family income splitting and thus eliminate attendant administrative and enforcement problems. ${ }^{75}$

$69 I d$. at 120 .

70 Literature on income splitting techniques is voluminous. See, e.g., Alter, The Family Business, N.Y.U. 16TH INST. ON FED. TAX. 755 (1958) ; Davies, Shifting of Fanily Income for Tax Purposes, 6 ST. LouIs U.L.J. 281 (1961); Yohlin, Assignment and Deflection of Income, N.Y.U. 20TH INST. ON FED. TAX. 147 (1962); Note, Fanily Partnerships and the Federal Income Tax, 41 IND. L.J. 684 (1966).

71 A similar rationale supports the Commission's provision of tax immunity for intrafamily property transfers. Transfer tax burdens can differ between various families, depending upon the legal ownership of family assets, the inter vivos gifts made, and the circumstance of which spouse dies first. The Commission provides this illustration. Families $A, B$ and $C$ have each accumulated $\$ 200,000$. Presumably, both husband and wife have contributed to this amount in one way or another. In $A$ all the assets are owned by the husband and in $B$ by the husband and wife, one-half each (as a result of gifts or otherwise). If the husbands in $A$ and $B$ die before their wives, the estate tax will be much greater for family $A$ than $B$. If in each family the wife dies first, family $B$ will pay much heavier estate taxes. Meanwhile, family $C$ might avoid estate taxes on the deaths of both spouses by having part of its assets accumulated in trust for the children. And if the husband in $A$ makes a substantial gift before death to his wife or children, a gift tax might result that families $B$ and $C$ would have avoided. These inequalities are eliminated by removing intrafamily transfers of property from the purview of the system. See 3 REPORT 119-20.

72 For a discussion of these provisions, see E. Mockler, J. Smith \& C. Frenette, Studies of the Royal Conarission on Taxation, Taxation of the family 3-38 (the Studies were prepared for the Commission and not by it).

733 RePORT 121.

741 REPORT 18; 3 REPORT 122; for additional anomalies see $i d$. at 121.

751 REPORT 18. 
II. The Internal Revenue Code's Treatment of the Family

The Internal Revenue Code's treatment of the family is often and intensely maligned. ${ }^{76}$ The Code's patchwork treatment stands in marked contrast to the comprehensive family unit of the Commission.

\section{Recognition of the Family}

The Code does not formally recognize the family as an entity; however, a taxpayer's marital and family relationships are taken into account for some purposes. Separate rate schedules are maintained for married couples, surviving spouses with dependent children, ${ }^{77}$ and heads of households; ${ }^{78}$ dependency exemptions are provided; ${ }^{79}$ deductions are allowed for certain alimony payments, ${ }^{80}$ medical expenses for dependents, ${ }^{81}$ and expenses for care of certain dependents; ${ }^{82}$ no deduction is allowed for certain losses, expenses and interest with respect to transactions between brothers, sisters, spouses, ancestors and lineal descendants; ${ }^{83}$ constructive ownership through spouses, children, grandchildren, and parents is employed in the treatment of certain corporate distributions and adjustments; ${ }^{84}$ a deduction of up to onehalf of the adjusted gross estate is allowed for bequests to the surviving spouse; ${ }^{85}$ gifts by one spouse to a person other than his spouse may, with consent, be treated as if given one-half by each spouse; ${ }^{86}$ and a gift to a donor's spouse entitles the donor to exclude one-half of the gift in computing his taxable gifts for the year. ${ }^{87}$

On the other hand, individual family members often are-or, at their discretion, can be-treated as isolated units: husband and wife can file individual income tax returns ${ }^{88}$ and unmarried persons, including dependent children, must; ${ }^{89}$ gains on sales to spouses, children and certain other relatives are recognized as income, ${ }^{90}$ as are gifts ${ }^{91}$ and bequests ${ }^{92}$ to spouses, children and other relatives.

76 See, e.g., Groves, supra note 1, at 3: "A considerable number of [tax] critics . . are firmly convinced that our present tax treatment of the family is irrational and inexpedient."

77 INT. REV. CoDE of 1954, §2.

78 Id. $\$ 1(\mathrm{~b})$.

79 Id. $\$ 151$.

80 Id. \$ 215 .

81 Id. $\$ 213$.

82 Id. $\$ 214$.

83 Id. § 267.

84 Id. $\$ 318$.

85 Id. $\$ 2056$.

86 Id. \$ 2513.

87 Id. $\$ 2523$.

88 Id. $\$ 1$.

89 In certain circumstances, a surviving spouse who has not remarried can file jointly with the deceased spouse. Id. $\$ \S 2,6013$.

90 Id. $\$ \$ 267,1002$.

91 Id. $\$ 2501$.

92 Id. $\$ 2001$. 
Dependent children are not, for purposes of income measurement and income tax assessment, included in their parents' unit. ${ }^{93}$ Prior to 1948 there were a few suggestions that the income of minor children be reported with that of the parents. ${ }^{94}$ Apparently, the question of children's income was not considered by Congress at the time of the 1948 tax reforms. ${ }^{95}$ Since then some attention has been given to the question and reportedly "many tax scholars" now favor inclusion of minor children in the parents' unit. ${ }^{96}$ Some would limit the inclusion to a child's property income or, more narrowly, to a child's income deriving from property received initially from a parent. ${ }^{97}$

Criticism of independent income taxation of children is based largely on equitable grounds. In terms of horizontal equity, families with the same total income are unequally treated depending upon how the income is distributed among the members. The distributions of income within a family can often be affected by various income splitting devices. ${ }^{98}$ In terms of vertical equity, there are two flaws in exclusion of children. One is that the income of children in high income families is taxed at the lowest marginal rates, if at all, when in fact the children's income is available, at least beneficially and indirectly, to the parents. $^{99}$ The other involves the double $\$ 600$ exemption possible in the case of a child who is a student, under 19 years of age, or earns less than $\$ 600$ annually. The double exemption arises when a child takes the exemption on his return ${ }^{100}$ and the parents, if qualifying, claim him as a dependent and take a similar exemption in their return. ${ }^{101}$ This means discrimination against lower income families because the parents are less likely to qualify for the dependency exemption (which requires provision of one half the child's support), lower income families being able to contribute less to the child's support while the child is more likely to be making a substantial contribution

93 Two other areas of criticism-treatment of heads of households and working wives-arguably functions of structured recognition, are treated under burden allocation infra at notes $127-35$ and accompanying text.

04 D. Thorson, The Selection of a Tax Unit Under the Income Tax: The INDIVIDUAL UNIT VERSUS THE FAMILY UNIT 75 (1962) (unpublished doctoral thesis submitted to the University of Wisconsin) [hereinafter cited as THORSON, SELECTION oF A TAX UNIT]. For several such suggestions, see DIVISION of TAX RESEARCH, U.S. TREasury Dep'T, The Tax TREatMent of FAMILY Incone, reprinted in Hearings on Proposed Revisions of the Internal Code Before the House Comm. on Ways and Means, 80th Cong., 1st Sess. 846, 861-63, 865-66 (1947); Ervin, Federal Taxes and the Family, 20 S. CAL. L. REv. 243, 247-48 (1947).

95 Thorson, Selection of a TAX UNiT 242.

96 Thorson, An Analysis of the Sontces of Continued Controversy over the Tax Treatment of Family Income, 18 NAT'L TAX J. 113, 130 (1965) [hereinafter cited as Thorson, Tax Treatment of Family Income].

97 See Groves, supra note 1 , at $42,100$.

98 The inequity is facilitated by the fact that earned income cannot be split, or dispersed, within the family while unearned income can be.

$99 \mathrm{~A}$ child's income is taxed to him even if payments for his services are made to his parents. INT. REv. CODE OF 1954, § 73.

$100 I d . \$ 151(\mathrm{~b})$.

101 Id. $\$ \S 151(\mathrm{e}), 152$. 
on his own. ${ }^{102}$ It also means that qualifying families receive a $\$ 1200$ exemption for the child, with a limiting effect on the progressivity of the tax rate applied to the total family income.

\section{Allocation of the Income Tax Burden to Families}

The least reasonable and most criticized aspect of the Code's treatment of the family is the allocation of income taxes among single persons and families. The Code's treatment appears to be more accidental than coherent. Joseph A. Pechman has observed that it is indeed "time to clean up the messy and arbitrary differences in the tax burdens of single and married people." 103

The central feature of allocation between single persons and couples under the Code is the split-income rates allowed couples. ${ }^{104}$ Under this provision, a couple halves its taxable income and pays a tax of twice the tax liability on the half. ${ }^{105}$ Heads of households, meanwhile, receive one half the split-income advantage. ${ }^{106}$ The following table illustrates the impact of split-income rates. ${ }^{107}$

\begin{tabular}{|c|c|c|c|c|c|}
\hline $\begin{array}{l}\text { Taxable } \\
\text { Income }\end{array}$ & $\begin{array}{l}\text { Rate on } \\
\text { Single } \\
\text { Return }\end{array}$ & $\begin{array}{l}\text { Rate on } \\
\quad \text { Joint } \\
\text { Return } 108\end{array}$ & $\begin{array}{l}\text { Tax on } \\
\text { Single } \\
\text { Return }\end{array}$ & $\begin{array}{c}\text { Tax Reduc- } \\
\text { tion on } \\
\text { Joint Return }\end{array}$ & $\begin{array}{c}\text { Percentage } \\
\text { Reduction } \\
\text { on Tax on } \\
\text { Joint Return }\end{array}$ \\
\hline$\$ \quad 500$ & $14.0 \%$ & $14.0 \%$ & 70 & 0 & $0 \%$ \\
\hline 1,000 & $14.5 \%$ & $14.0 \%$ & 145 & 5 & $3 \%$ \\
\hline 2,000 & $15.5 \%$ & $14.5 \%$ & 310 & 20 & $6 \%$ \\
\hline 3,000 & $16.7 \%$ & $15.0 \%$ & 500 & 50 & $10 \%$ \\
\hline 6,000 & $18.7 \%$ & $16.7 \%$ & 1,130 & 130 & $10 \%$ \\
\hline 10,000 & $21.9 \%$ & $17.2 \%$ & 2,190 & 470 & $22 \%$ \\
\hline 14,000 & $25.4 \%$ & $19.7 \%$ & 3,550 & 790 & $22 \%$ \\
\hline 20,000 & $30.4 \%$ & $21.9 \%$ & 6,070 & 1,690 & $28 \%$ \\
\hline 26,000 & $34.8 \%$ & $24.6 \%$ & 9,030 & 2,650 & $29 \%$ \\
\hline 32,000 & $38.2 \%$ & $26.9 \%$ & 12,210 & 3,550 & $29 \%$ \\
\hline 40,000 & $41.7 \%$ & $30.3 \%$ & 16,670 & 4,530 & $28 \%$ \\
\hline 50,000 & $46.4 \%$ & $34.1 \%$ & 22,590 & 5,530 & $24 \%$ \\
\hline 100,000 & $55.5 \%$ & $45.2 \%$ & 55,490 & 10,310 & $19 \%$ \\
\hline 200,000 & $62.7 \%$ & $55.5 \%$ & 125,490 & 14,510 & $13 \%$ \\
\hline 400,000 & $66.4 \%$ & $62.7 \%$ & 265,490 & 14,510 & $5 \%$ \\
\hline
\end{tabular}

Split-income rates are subject to sharp criticism not only with respect to differentiation between single persons and couples but for

102 Cf. Groves supra note 1 , at $39-41$. The inequity is compounded by the greater worth, in taxes saved, of exemptions to higher tax bracket families.

103 Pechman, Incone Splitting, 1 TAX Revision Compendium 473, 486 (1959) (paper submitted to House Comm. on Ways and Means),

104 Split-income rates are to be distinguished from income splitting, see text accompanying notes 69-70 supra, which is income deffection or dispersion through devices such as trusts or gifts of income-producing property.

105 INT. REV. CODE OF 1954, \&2.

106 J. Pechman, Federal Tax Policx 83-84 (1966). Int. Rev. Code of 1954, $\$ 1$ (b) (1), provides the rate schedule for heads of households, as defined by $\$ 1(\mathrm{~b})(2)$ $\&(3)$.

107 Figures are based on INT. REv. CoDE of 1954, § 1(a) (2).

108 The rate is arrived at by dividing the tax by the taxable income. 
their effect on progressivity as well. ${ }^{109}$ As the table indicates, middle and upper income couples receive a substantial tax reduction, a maximum of 29 per cent at the $\$ 26,000-\$ 32,000$ level. Approximately 66.5 per cent of all returns either cannot claim the benefits of splitting or receive little benefit from it and only about 17 per cent of all returns receive significantly more than a $\$ 40$ benefit. ${ }^{110}$ The revenue lost by the use of split-income rates instead of individual reporting was estimated in 1959 to be over $\$ 4$ billion a year. ${ }^{111}$

The net result of split-income rates, therefore, is a disproportionate reduction to middle and upper income couples (especially the latter) at the ultimate expense of single persons and lower income couples. ${ }^{112}$ Even without recalling the Royal Commission's goal of sensitive adjustments in relation to the economies of marriage at various income levels, ${ }^{113}$ split-income rates are clearly haphazard and inequitable.

Split-income rates originated in 1948. Their adoption has been attributed to "historical developments rather than design" and to "political compromise dictated by a high-pressure historical situation." 114 Split-income rates resolved two problems: the discrimination in favor of couples in community property states who could split their income in separate returns while couples in other states could not, and the unequal treatment of couples with like incomes in non-community property states based on the distribution of income between husband and wife, with the least tax liability arising from an equal distribution. ${ }^{115}$ Aggregation of the incomes of husband and wife was a logical step in the resolution of these problems; split-income rates as a means of burden allocation was not.

Split-income rates have been popular, despite their flaws, and Congress has not seriously considered alternatives. ${ }^{116}$ Nonetheless, justifications for their disparities are few. One is that the benefits accruing to middle and upper income families are appropriate in view of the alleged failure of personal exemptions to provide adequate relief for the costs of raising children. However, lower income couples may also have children; and split-income rates at any event do not distinguish between childless and childbearing couples. ${ }^{117}$ It is also argued

109 See, e.g. J. Due, Government Finance 155-56 (1959); Musgrave, Hoze Progressive is the Income Tax? 3 TAx Revision Compendum 2223 (split-income treatment "punctures the pattern of progression . . . in an arbitrary and inequitable fashion") ; Pechman, supra note 103, at 473-86.

110 Groves, supra note 1 , at $72-73$.

111 Pechman, supra note 103, at 474.

112 Professor Groves terms the treatment of singles "unconscionable." Groves, supra note 1 , at 106.

113 See notes 35-39 supra and accompanying text.

114 Groves, supre note 1 , at 17, 59. Accord, Oldman \& Temple, Comparative Analysis of the Taxation of Married Persons, 12 Stan. L. Rev. 585, 593-94 (1960)

[hereinafter cited as Oldman \& Temple].

115 Pechman, supra note 103 , at 473.

116 J. Pechanan, Federal Tax Policy 84 (1966).

117 Id. 
that splitting eliminates the disincentive to a wife's working inherent in income aggregation. 118 A third defense is that it is "a necessary incentive for advancement to executives and professional people." 118

The Code further differentiates on the basis of marital status and family responsibility through the personal and dependency exemptions, allowing $\$ 600$ deductions for the taxpayer, his spouse, and each of his qualifying dependents. ${ }^{120}$ It is helpful to consider at the same time the standard deduction of up to $\$ 1,000$, computed as the larger of 10 per cent of adjusted gross income or $\$ 200$ plus $\$ 100$ for each exemption claimed under section 151.21 The standard deduction is, in a sense, simply an additional exemption, ${ }^{122}$ and is claimed on about 65 per cent of all returns. ${ }^{123}$

The following table indicates the extent to which the $\$ 600$ exemptions and standard deduction insulate income from taxation among various family groupings. Included in the table are comparative figures based on data contained in a Study by the Survey Research Center, Institute for Social Research, at the University of Michigan with respect to costs of living and the percentages of these covered by the minimum amounts of income insulated by the exemptions. ${ }^{124}$

118 See Groves, supra note 1 , at 76.

119 See Groves, supra note 1, at 76-77. A related defense is that increasing the tax burden on upper income taxpayers would only lead to higher professional charges to offset the increase, which in turn would pose the prospect of inflation. Brenner, $A n$ Inquiry into the Passibility of Lowering the Tax Rates by Increasing the Tax Base through Elimination of Income Splitting, 1 TAX Revision CoMpendum 487, 492 (1959).

120 INT. REv. CoDE of 1954, $\S \S 151,152$. For a discussion of various rationales of exemptions, see Groves, supra note 1 , at 23-26; Bittker, $A$ "Comprehensive Tax Base" as a Goal of Income Tax Reform, 80 Harv. L. REv. 925, 940-43 (1967) ; Kassalow, To Restore Balance and Equity in Family Income Taxation, 1 TAX REvisron ComPENDIUM 515 (1959); Pechman, What Would a Comprehensive Individual Income Tax Yield?, id. at 251, 266, 267. For consideration of the alleged inadequacies of the exemptions in view of the various rationales, see Groves, supra note 1, at 29,45; J. PEChMan, Federal TAX Policy 69-70 (1966). For the revenue costs of the exemption and of increasing the $\$ 600$ amount, see $i d$. at 71 ; Bittker, $A$ "Comprehensive Tax Base" as a Goal of Income Tax Reform, 80 HARv. L. Rev. 925, 940 (1967); Magill, Federal Income Tat Revision, 1 Tax Revision Compendium 87, 92 (1959). For alternative forms of exemptions, see Groves, supra note 1, at 34-38; Note, $A$ Proposed Flexible Personal Exemption for the Federal Income Tax, 18 STAN. L. Rev. 1162 (1966).

121 INT. REv. CODE oF 1954, §141. Where husband and wife file separately, the deduction is reduced. Id. $\$ 141$ (c), (d).

122 Groves, supra note 1 , at 43 . The standard deduction is an additional exemption in that it is an automatic deduction in computing taxable income. However, it is taken in lieu of itemizing specific deductions and thus is not a free, automatic deduction for all taxpayers.

123 Seltzer, The Place of the Personal Exemption in the Present-Day Income Tax, 1 TAX Revision Compendium 505 (1959).

124 J. Morgan, M. David, M. Cohen \& H. Brazer, Income and Welfare in the UNITED States 189 (1962). [hereinafter cited as MORGAN]. The figures are provided for the purposes of comparison and not to point up the adequacies or inadequacies of the exemptions with respect to a minimum cost of living, subsistence, etc.

It is assumed that the husband is employed, the wife not employed; costs for children are averaged for different aged children. 


\begin{tabular}{lccc}
\multicolumn{3}{c}{$\begin{array}{c}\text { Exemptions and } \\
\text { Minimum }\end{array}$} & \\
& $\begin{array}{c}\text { Standard } \\
\text { Deductions }\end{array}$ & $\begin{array}{c}\text { Cost of } \\
\text { Taxping }\end{array}$ & $\begin{array}{c}\text { Per cent of } \\
\text { Coverage }\end{array}$ \\
Individual & $\$ 900$ & $\$ 2,284$ & 39 \\
Husband and Wife & 1,600 & 3,038 & 52 \\
Husband and Wife & & & \\
$\quad$ plus & & & \\
1 child & 2,300 & 3,688 & 62 \\
2 children & 3,000 & 4,278 & 70 \\
3 children & 3,700 & 4,926 & 75 \\
4 children & 4,400 & 5,682 & 78 \\
5 children & 5,100 & 6,332 & 81
\end{tabular}

The ratio between the above exemptions is .6 (single) : 1.0 (couple): 1.4 (couple with child) : 1.9 (couple with two children). In marked contrast, the cost of living ratio from the above table is: .7 (single): 1.0 (couple) : 1.2 (couple with child) : 1.4 (couple with two children). Professor Groves and Joseph A. Pechman report similar ratios on the basis of other cost of living studies. ${ }^{125}$ In relative terms, therefore, couples and their children receive exemptions considerably out of proportion, from a cost of living standpoint, to those allowed single persons. ${ }^{126}$

The Code is also criticized for its failure to take direct account of a wife's employment. Split-income rates, it will be remembered, do not distinguish between income-earning and non-income-earning wives. The appropriateness of such a distinction is clear. ${ }^{127}$ Apparently, the matter received no consideration by Congress in 1948 and only slight consideration in $1954 .{ }^{128}$ The Code indirectly accounts for a working wife's expenses (or imputed income lost) by conceding a working mother a deduction up to $\$ 900$ for expenses of caring for children infirm or under 13 years of age, if incurred "for the purpose of enabling the taxpayer [a woman or widower, or husband whose wife is incapacitated or institutionalized] to be gainfully employed." ${ }^{129}$ The

125 Groves, supra note 1 , at 28 n.15; J. PeCharan, Federal Tax Policy 67-69 (1966).

126 See notes 100-01 supra and accompanying text.

127 See, e.g., GRovEs, supra note 1, at 17 ("Differentiation between married couples with two jobs and those with one is at least as compelling as that between married couples and single persons"); Atlas, Personal Exemptions, 1 TAx Revisron Compendium 525, 530 (1959); Oldman \& Temple 603; Thorson, Tax Treatment of Family Income 116.

128 Thorson, Selection of the TAX UNit 243.

129 INT. REv. Cone of 1954, \$214. 
deduction has been castigated as inadequate and less than one half what it should be. ${ }^{130}$

Finally, the Code is criticized for its treatment of heads of households. ${ }^{131}$ Section $1(b)$ provides one half the split-income benefit ${ }^{132}$ to an unmarried taxpayer who maintains a household which is the principal place of abode of his child or a section 151 dependent, including a parent. Section 2 allows a surviving spouse with a section 151 dependent child living at the spouse's place of abode full split-income benefit for two years after the death of his spouse. The provisions are faulted on a number of grounds. One is that, in the case of section 1 (b), one half the split-income benefit is insufficient. It is argued that heads of households may have no greater taxpaying ability than some married couples with the same taxable income. Another is the requirement that the dependent live with the taxpayer, when in fact the cost of supporting the dependent elsewhere may be more costly..$^{133}$ A House proposal in 1954 to liberalize the head-of-household provision to allow full splitting (irrespective of whether the dependent lived with the taxpayer) was rejected by the Senate. ${ }^{134}$ Professor Groves states that "[p] robably most critics would agree that the rationale of all these classifications is tenuous." ${ }^{135}$

\section{Taxation of Intrafamily Property Transfers}

As a general rule, transfers of property between members of a family are within the purview of the Code and are subject to transfer taxation, in the case of gifts and bequests, and to income tax in the case of transfers for value. Several Code provisions qualify this rule. Section 267 provides that losses on certain sales between related taxpayers are not recognized. For estate tax purposes, section 2056 allows as a deduction from a decedent's gross estate "an amount equal to the value of any interest in property which passes or has passed from the decedent to his surviving spouse . . . to the extent that such interest is included in determining the value of the gross estate," up to one half the value of the adjusted gross estate. For gift tax purposes, section 2523 allows a donor a deduction (in computing taxable gifts) of one half the value of his gifts to a spouse. No provisions expressly immunize intrafamily gifts and bequests to children, although children may of course benefit indirectly from the limited immunity

130 Groves, supra note 1 , at 82 . For interesting statistics on the frequency and costs of child care, see MORGAN 111-12 (indicating, inter alia, that of two-job families with children under six years of age-presumably the age of entry into school-one half do not pay anything for child care).

131 See, e.g., Groves, supra note 1 , at 17,69; J. Pechman, Federal Tax Policy

84 (1966) ; Pechman, supra note 103, at 481-85.

132 J. Pechiman, Federal Tax Policy 83 (1966).

133 Pechman, supra note 103 , at 482.

134 Groves, supra note 1 , at 69 ; Pechman, supra note 103 , at 482-83.

135 Groves, supra note 1 , at 69 . 
granted interspousal transfers. Also, spouses and children may benefit from the $\$ 60,000$ estate tax exemption of section 2052 and $\$ 3,000$ annual and $\$ 30,000$ lifetime gift tax exemption of sections 2503 (b) and 2521 , respectively.

Sections 2056 and 2523 were new to the Code in 1948, and, like the split-income rates of that year, were the result of "a political compromise dictated by a high-pressure historical situation and . . . were hardly a deliberate choice made after all the equities and other consequences were weighed." 136 In purpose the sections represent an attempt to equalize federal estate and gift tax treatment of spouses in common law states with those in community property states. Their failure to fully achieve this objective is often decried. ${ }^{137}$

Critics of transfer taxes on interspousal transfers are legion. After a conference of experts on federal estate and gift taxation sponsored by the Brookings Institution, Carl Shoup reported that a majority of the conferees favored complete interspousal immunity. ${ }^{138}$ Professors Casner and Andrews, in their recent work on the American Law Institute Federal Estate and Gift Tax Project, have recommended complete interspousal immunity from transfer taxation. ${ }^{139}$ Professor Casner states the case for the critics:

[Immunity] is designed to simplify the handling of property dispositions between husband and wife; to lessen the economic adjustment that may now be required, when the earning power of a spouse ceases on death, by making it possible to avoid any transfer tax payment at such time; to make the impact of the transfer tax felt in the same degree regardless of the state in which the transferor resides; and to carry out the philosophy of the average husband and wife who regard the property they own as "our" property. ${ }^{140}$

There is likewise considerable criticism of the Code's failure to provide immunity to certain parent-child transfers. The criticism has focused on bequests, stressing the inequity of taxing bequests to dependent children and students for their support and education. Had the parent lived, there would have been no transfer tax on such amounts. As already mentioned, some such amounts can be transferred to the child indirectly and free of taxation by bequest to a surviving spouse who can in turn provide the child with support and

136 Id. at $59-60$.

137 See, e.g., J. Pechman, Federat Tax Policy 186 (1966) ; C. Shoup, Federal Estate AND GIFT TAXes 51-52 (1966) [hereinafter cited as SHoup]. See generally 38 CalIF. L. Rev. 1-182 (1950); 22 TaX L. Rev. 515-684 (1967). 138 Shoup 122; cf. DeWind, The Approaching Crisis in Federal Estate and Gift Taxation, 38 CALIF. L. REv. 79, 110 (1950).

139 Andrews, The Accessions Tax Proposal, 22 TAx. L. Rev. 589, 592 (1967);

Casner, American Law Institute Federal Estate and Gift Tax Project, id. at 515.

140 Casner, supra note 139 , at 549. 
education. The participants in the Brookings conference referred to above agreed that some allowance should be made for bequests made to children. ${ }^{141}$ One proposed set of mechanics would allow an estate with no surviving spouse a $\$ 3,000$ deduction for each year by which each recipient child is under 21 years of age. ${ }^{142}$ Bills have been introduced in Congress to ease the tax on transfers to dependent children. ${ }^{143}$

\section{An Evaluation}

Complete and accurate evaluation of the Commission's family unit will be possible, if ever, only after implementation of statutory provisions which evolve from the proposal. Even then the evaluation will depend upon other components of the tax system into which the family unit is introduced. What follows is an examination of the Commission's family unit on three interrelated levels. The principle level is theoretical, apart from either the full context of the Report or that of the Internal Revenue Code, and confronts the question how the family should be treated by a tax system. The second level consists of evaluation of the family unit in the context of the Report, including the Income Adjustment Account and treatment of gifts and bequests as income. Third, and least emphasized, is analysis in the context of the Internal Revenue Code, notably with respect to its transfer taxation.

\section{Structure}

An income tax system must initially define the appropriate tax unit or units. Income must be measured and reported, assessments and payments made. While the tax unit is a necessary first step, the focal point of an income tax system is, of course, its allocation of the tax burden. ${ }^{144}$ In turn, the choice of units is one focal point of the controversy over allocation of the burden among various family and individual groupings at various income levels. ${ }^{145}$ Given a philosophy of progressive taxation-whatever, exactly, it may be ${ }^{146}$-that takes

141 Shoup 122-23, 132.

142 Id. at 59.

143 E.g., H.R. 1845, 88th Cong., 1st Sess. (1963). See also Children's Estate Tax Deduction, Hearings on H.R. 7924 Before the House Comm. on Ways and Means, 86th Cong., 1st Sess. (1959).

It will be recognized that the support and education argument for an allowance on bequests to minor children is inapplicable to inter vivos gifts and to bequests in excess of the child's support and education needs during minority.

144 See, e.g., Groves, supra note 1 , at 105, British Royal Commission on the Taxation of Profits and Income, Second Report, $\mathbb{1} 116$, at 35 (1954).

145 See, e.g., Oldman \& Temple 585.

${ }^{146}$ A precise philosophy of progressive taxation is of course basic to tax treatment of the family. As Professor Groves has noted, "Underlying all of the specific problems of family taxation are conflicting philosophies of equity in taxation." Groves, supra note 1, at 3. Full discussion of these issues is beyond the scope of this Comment; however, they are confronted briefly in the discussion of allocation of the income tax burden at text accompanying notes $190-92$ infra. 
account of personal circumstances, ${ }^{147}$ the tax unit should then be structured to facilitate this philosophy, as well as such other goals of taxation as enforcement and administration.

The Commission appears quite correct in recommending a supplement to Canada's present individual unit. To be sure, the individual unit has been defended from time to time. A. P. Herbert once declared that combining the incomes of husband and wife "is in effect a tax upon marriage and a tax upon virtue." 148 Further, it has been argued that, conceptually,

the family as a unit has no combined taxpaying ability per se; that its taxpaying ability is composed of the separate taxpaying abilities of its individual members; and that the taxpaying ability of each of these is determined by the amount of income of which he or she is the owner without reference to the income of other members of the family. ${ }^{149}$

Japan, Australia and many of the states in this country use only the individual as an income tax unit.

Nonetheless, the case for inclusion of husband and wife as a single unit is compelling. The Commission's analysis of the economic and social utility of husband and wife, and the equitable, administrative and enforcement advantages of the family unit ${ }^{150}$ amply explain the broad consensus among tax critics. ${ }^{151}$ Equally well entrenchedat least since the 1948 congressional tax revisions-are the notions that state-determined property rights ${ }^{152}$ and a wife's citizenship or legal equality ${ }^{153}$ are not barriers to the inclusion of husband and wife in one unit.

147 The secondary and related question of the propriety of taking account of various family responsibilities in burden allocation is considered at text accompanying notes 185-89 infra.

118 A. Herbert, The Uncommon Law 237 (1936).

149 Division of Tax Research, U.S. Treasury Dep't., The Tax Treatment of FAmmy Incone, reprinted in Hearings on Proposed Revisions of the Internal Revemue Code Before the Honse Comm. on Ways and Means, 80th Cong., 1st Sess., 846, 851 (1947). Oldman \& Temple, at 603, argue that the individual unit can be justified only if it is impossible to establish a family unit entailing fewer inequities.

150 See notes $61-75$ supra and accompanying text.

$151 \mathrm{On}$ the financial, economic and decision-making unity of husband and wife, see E. LeiMasters, Modern Courtship and Marriage 466-68 (1957); Morgan 23; J. Pechasan, Federar Tax Policy 83 (1966) (noting that there is less economic unity at high income levels); Oldman \& Temple 596-98; Thorson, Tax Treatment of Fanily Income 115-16.

152 See, e.g., Thorson, $i d$. at 115 . The spirit of the state property rights approach is apparent in Justice Roberts' opinion in Poe v. Seaborn, 282 U.S. 101 (1930):

We are of opinion that under the law of Washington the entire property and income of the community can no more be said to be that of the husband, than it could rightly be termed that of the wife.

The District Court was right in holding that the husband and wife were entitled to file separate returns, each treating one-half of the community income as his or her respective income ....

Id. at $113,118$.

153 See, e.g., Groves, supra note 1, at 70; Oldman \& Temple 602. 
However, a significant problem raised by inclusion of the wife in the tax unit is that she may be discouraged from working. Aggregation of the wife's income with that of her husband means that her income is taxed at least at her husband's marginal rate, and most likely at a higher rate due to the likelihood that the combined incomes will fall into a higher bracket. ${ }^{154}$ But because a wife's income probably gives the couple greater "discretionary economic power," a greater tax burden is appropriate.

The Commission, however, unnecessarily discourages wives from working by failing to make proper adjustment for a working wife's additional expenses and the imputed income lost to the family. ${ }^{155}$ Failure to take account of these items, which in itself departs from the concept of "discretionary economic power," compounds the inevitable disincentive resulting from aggregation. The Commission's view is that while working wives may incur "some additional family housekeeping expenses," "[m]any of these expenses are nothing more than a purchase of increased leisure time and freedom from unpleasant housekeeping tasks." ${ }^{158}$ The Commission would grant a family unit with a working mother an $\$ 80$ tax credit (a reduction of the total tax the unit would otherwise have to pay) if there are children in the unit, or $\$ 120$ if there is a child under seven..$^{157}$ The family rate schedule itself does not differentiate between one- and two-worker families.

Arrayed against the Commission's view of the working wife is a consensus among economists and tax commentators that a married couple with a working wife should be treated differently from a couple in which the wife is not working. This need to differentiate has been termed as great as the need to differentiate couples from single persons. ${ }^{158}$ One study of family budget costs concluded that the annual cost of goods and services for an employed wife was $\$ 1,092$, compared with $\$ 546$ for a nonworking wife. ${ }^{159}$ Arguably the credits for working mothers compensate in part for the failure to provide a working wife's allowance, assuming that many working wives are mothers as well. However, at least some wives would be discouraged from working; this, it has been suggested, could have considerable

154 For the changes in tax liability resulting from the aggregation of income of husbands and wives who would otherwise be taxed as individuals, see 3 REPORT 191 (table 11-15).

155 See text accompanying note 159 infra.

158 3 REPORT 193, 210 n.22.

157 See note 45 supra and accompanying text.

158 See note 127 supra and accompanying text.

159 MoRgan 189 (figures from the Community Council of Greater New York, Budget Standard Service, Annual Price Survey and Family Budget Costs, October, 1959). 
impact on middle class two-job families. ${ }^{160}$

One of the most debatable aspects of the Commission's family unit is its inclusion of dependent children. On the theoretical level, it is clear that the conceptual neatness of including husband and wife in a unit does not appear in the case of dependent children. A child is only a temporary member of the family. While it may be true that "[w]e think in terms of dad, mom, and the kids," 161 pooling and sharing income with a child does not occur to the same degree as between husband and wife. ${ }^{162}$ A child's income is frequently regarded as his spending money and outside the family budget, especially in higher income families; and he is not as directly a part of the decision-making process within the family as are the husband and wife. On the other hand, even if there is not always pooling and sharing with children, there generally is some, and the income of the child is at least indirectly available to the family as a whole, relieving the family of some of the child's expenses. ${ }^{163}$

It is of course possible that inclusion of dependent children within the family unit might discourage some children from working. ${ }^{164}$ A proposal in the state of New York to aggregate a child's income with that of his parents led some parents to assert that they would ask their children to stop working. ${ }^{165}$ Putting aside the psychological aspects of inclusion, the incentive argument is not persuasive. A survey conducted in the United States found that only 6 per cent of "spending units" (defined as a group of relatives living together and pooling their incomes for major items of expense) contained children under 18 earning money, only 1 per cent contained children earning $\$ 500$ 999 annually and only 1 per cent contained children earning over $\$ 1,000 .^{168}$ Such small amounts, especially if an exemption is provided, would not be likely to raise the family's marginal rate. And, in the United States at least, the marginal rate for the "vast majority"

160 See Remarks of Frank E. A. Sander, Canadian Tax Foundation 17, 21. Presumably, wives in lower income families are in sufficiently great need of income for consumption purposes that the disincentive is not crucial; upper income wives inclined to work (of whom there are likely fewer than in lower income families), meanwhile, arguably are not greatly influenced by the relatively slight amounts represented by the disincentive.

101 E. MockLer, supra note 72, at 75.

162 D. Thorson, Selection of a TAX Unit 189.

163 Id.; see Groves, supra note 1, at 34, 70; Surrey, Federal Taxation of the Family-The Revemue Act of 1948, 61 HARV. L. REv. 1097, 1114 (1948).

164 As with the working wife, the child's income will be taxed at least at the family's marginal rate. See text accompanying note 154 supra.

165 N.Y. Times, March 1, 1960, at 1, col. 6.

166 See MoRgan, supra note 124, at 140 . These figures are not comprehensive for purposes of the Commission's family unit because children 19,20 and 21 are not included, nor are students $22-25$ who could remain in the family unit. Nonetheless, they are indicative of the slight amounts of earned income that would generally be aggregated with parental income. 
of children will be among the lowest irrespective of inclusion. ${ }^{167}$ Furthermore, lower and middle income children of working age often must work to help to pay for their support and education in any event. There is little doubt, however, that there will be some disincentive in high income families. ${ }^{168}$

A third point, related to the incentive issue, is the impact of inclusion of dependent children's gifts and bequests from persons outside the family unit. Inclusion means that any income produced by such property (be it in trust, securities or whatever) is taxed at the family's marginal rate. This could well discourage the making of gifts that would increase the family's marginal rate and the amount of tax directly attributable to the income produced by the donated property. In turn, increasing the family rate can be said to constitute a disincentive for the child to work.

Fourth, it might be argued that a sound tax policy would be to provide low rates for children in order both to encourage them to work and to subsidize their education. However, as indicated above, it is unlikely that children would be significantly deterred from working by inclusion. While inclusion might thwart a policy designed to subsidize education, it is questionable that encouraging children to work is the best, or even an appropriate, method of providing for the expenses of education.

Fifth, it may be argued that inclusion would result in enforcement problems, principally because increased rates would provide greater incentive for avoidance. ${ }^{169}$ However, an exemption (such as the Commission's $\$ 500$ one) will mitigate the impact of any increase in rate and such an exemption, combined with the reporting of income by employers, should solve any problems that do arise.

Finally, aggregation may appear harsh for large, low-income families in which there may be several working children, each of whom may receive little support from his parents. An annual exemption, such as the Commission's $\$ 500$ for earned income, alleviates this problem to a considerable degree. As a practical matter, there are few families with more than one or two working children and their earnings, in themselves or at least in excess of an exemption, are no doubt generally small. ${ }^{170}$ Further, older children with significant annual earnings could and presumably would leave the family unit.

In summary, the Commission's case for inclusion of dependent children is strong if not compelling. ${ }^{171}$ On a financial and social

167 Harriss, Parent and Child-And Taxes: Some Problems in Dependency, 1 TAx Revision CoMrendium 531, 532 (1959).

108 Cf. id.

169 Groves, supra note 1 , at 70 .

170 See note 166 supra and accompanying text.

171 It should be noted that other aspects of a tax system can militate against any single recommendation, including that of inclusion. For example, if adequate tax relief is not allowed a family for the expenses of raising children then indirect relief through separate taxation of children may seem more appropriate. 
analysis, they belong in the family unit. As a practical matter, inclusion should not amount to a significant disincentive for working children or donors outside the family unit. Inclusion would mean, quite reasonably, the application of the parents' tax rate to the child's income in excess of the exemption. It would also be equitable in ending the advantages of most income splitting within the family. Moreover, inclusion would end many of the administrative problems of enforcement of statutory provisions ${ }^{172}$ and judicial doctrines ${ }^{173}$ against family income splitting.

An analysis of the Commission's specific proposals for the inclusion of dependent children within the context of the full Report is now in order. First, the proposal that gifts and bequests from a person outside the tax unit constitute income to the recipient unit may mean that such gifts will be discouraged. Unless the gift is deposited in the Income Adjustment Account by the child, ${ }^{174}$ it comprises income to the family, and will likely raise the family's rate and then be taxed at that rate. This disincentive is in addition to the inevitable disincentive to any giving caused by treating gifts and bequests as income. ${ }^{175}$ Treating gifts as income also means potential difficulty for the child leaving the unit. Any property received from his parents subsequent to leaving constitutes income to him. Thus, so long as he is young enough to remain in his parents' unit, he must weigh the tax benefits of avoiding inclusion of his income with the family's against the detriment of having to pay taxes (after he leaves) on property received from his parents either while he was a member of the unit or at the time he leaves.

172 E.g., INT. REv. CODE of 1954, §§ 641-83 (trusts), 704(e) (family partnerships).

173 E.g., the rubrics "anticipatory assignment," "beneficial enjoyment," "control," and "fruit and tree" where used in a family setting.

A possible constitutional problem should be mentioned. The Supreme Court in 1931 held that a Wisconsin statute aggregating the income of husband, wife and dependent children under 18 years of age and applying a progressive income tax rate schedule to the total violated due process. Justice Roberts, speaking for the Court, said that "any attempt . . . to measure the tax on one person's property or income by reference to the property or income of another is contrary to due process . . . ." Hoeper v. Tax Comm'n of Wis., 284 U.S. 206, 215 (1931). Justices Holmes, Brandeis and Stone dissented. Since that time, however, courts in the United States have moved away from the "technical tests of local property laws," Groves, supra note 1, at 62, and have sustained other joint-return statutes. See, e.g., Ballester v. Court of Tax Appeals, 61 P.R.R. 460 (1943), aff'd sub nom. Ballester-Ripoll v. Court of Tax Appeals, 142 F.2d 11 (1st Cir. 1944), cert. denied, 323 U.S. 723 (1944); Albanese D'Imperio v. Secretary of the Treasury, 76 P.R.R. 302 (1954), aff'd 223 F.2d 413 (1st Cir.), cert. denied, 350 U.S. 874 (1955). It is to be expected that federal legislation taxing families as a unit would be held constitutional. See generally R. MAGILL, TAXABLE INCOME 329-34 (Rev. ed. 1945) (qualifying this conclusion as being "likely" where the tax liability is apportioned to family members); D. Thorson, SELECrION of A TAX UNIT 82-108.

174 The child's Account is different from the Account available to adult taxpayers, the latter being designed as an income-averaging provision which does not earn interest. See 3 REPORT 259-60, 269-73, 278-79.

175 Of course, increasing the family's rate in turn increases the possibility of disincentives to work. 
Second, the Commission proposes a number of provisions to ameliorate the harsher effects of inclusion. One is a $\$ 500$ exemption for a child's earned income. This is a strong counter to disincentive. Another provision is for an education credit, which counters the argument that inclusion will discourage education. ${ }^{176}$

Finally, the Commission proposes an Account into which income earned by a child in excess of $\$ 500$ and gifts from outside the family can be deposited. Amounts so deposited constitute income only upon their withdrawal from the Account, which can occur no later than the child's withdrawal from the unit. ${ }^{\mathbf{1 7 \pi}}$ The child's Account is a qualification on inclusion of children and an acknowledgment of their transient membership in the family unit. The Commission believes that without the Account these sums would be taxed first to the family and later to the child upon leaving the family unit. The Account thus acts to preserve incentive for a child to work and for donors outside the family to make gifts to children by effectuating a pass-through which avoids the double tax. The Account is treated below in detail. ${ }^{178}$

The Commission's standards for termination of a child's membership in the family unit are reasonable. With the exception of the provision for opting out, the termination events are automatic, and none are necessarily coincidental with the child's actual departure. However, most of them will be coincidental, and when combined with the administrative ease of automatic cutoffs, the Commission's choice of termination events seems appropriate.

A problem does exist, however, with married students. Treating gifts and bequests as income means that parental gifts for support and education made subsequent to the child's marriage ${ }^{179}$ are taxed to the child. ${ }^{180}$ Married students often continue-financially, at least-as members of their original families. One solution would be to permit bona fide, full time students to postpone formation of their own unit until they complete their full time education. A problem still would remain, however-how to treat the couple vis-à-vis their original families. The couple could be placed in the husband's (or wife's)

1763 REPORT 229-33. The proposed credit for expenses incurred for post-secondary education is an amount equal to one fourth of the "fees" paid, allowed to the unit of which the student is a member, plus an annual credit to the student's unit of up to $\$ 300$ for living costs if he is not a dependent child. Unused credits could be carried forward.

$177 I d$. at 136.

178 See text accompanying notes $243-63$ infra.

179 The education credit, note 172 supra, is not relevant at this juncture because (1) it is designed to encourage education, not to mitigate the harshness and conceptual inappropriateness of the deemed withdrawal, and (2) it does not change the result of income flows between two separate units but constitutes relief only for the paying unit. Similarly, the credit for support payments for once-dependent children provides relief only to the paying unit. See note 19 supra.

180 Such additional taxation would presumably create strong pressure on young students to avoid marriage, as those who could count on continued parental support would be able to avoid taxes on these payments until they reached the age of 25 . 
original family or each spouse could remain in his original unit. Optional filing with the respective original family units seems the more appropriate of the two solutions. Such a provision would, however, pose several problems. First, it would be necessary for both sets of parents to consent to the election. Where the student husband's family, for example, is supplying a portion of his wife's expenses, her family may be unwilling or unable to assume responsibility for taxes attributable to the inclusion in their income of these payments to their daughter. Also, it would not be easy to apportion payments to the student couple between husband and wife. Moreover, it is by no means clear how long a student couple should be permitted to put off forming a new unit. While a requirement that both husband and wife be fulltime students seems reasonable, it is also arguable that a couple should continue to qualify if the wife leaves school to raise a family.

A simpler approach for married students would be to provide their unit with an exemption for financial assistance received from either parental unit for educational and support purposes. While tuition will vary from school to school, a maximum support allowance could be fixed, and the exemption limited to the amount by which the couple's tuition and support expenses exceed their income from sources other than their parents. Husband and wife would still be deemed to have withdrawn from their original family units, thus preserving the conceptual integrity of withdrawal, and thereby eliminating the problem of determining when to deem withdrawal to have taken place if marriage is not to be the measuring event. Additionally, the exemption would alleviate the administrative difficulties of apportioning to husband and wife sums received by the couple from their parents. Despite its departure from the neatness of the Commission's "comprehensive tax base," the exemption seems the more appropriate means of accommodating the economic realities of married students.

The Commission's recommendation that the family unit not extend beyond husband, wife and dependent children is sensible. From some statistics gathered for the University of Michigan, it appears that the number of relatives ${ }^{181}$ living with the immediate family has decreased as living standards in the United States have risen, so that only 17 per cent of family heads provide housing for relatives. These 17 per cent average 1.4 relatives each. The average cost to each family is a net of $\$ 492$ a year for food and housing. ${ }^{182}$ Almost no one with an income of $\$ 5,000$ or more lives in a relative's house. Families with annual incomes of less than $\$ 1,000$ or over $\$ 15,000$ seldom take in relatives. ${ }^{183}$

181 "Relative," as here used, excludes spouses and children.

182 Morgan 173-79.

183 Id. at $163,170$. 
On the "entity" analysis, a close relative (for example, an elderly parent) living with a family may in fact share whatever income he has, but he is often more of a boarder than an integral part of the family. Inclusion in the context of the Commission's intrafamily transfer tax immunity would be most attractive to persons, relatives or not, who intended to make gifts or bequests to members of another unit. ${ }^{184}$ On the other hand, neither a close relative nor the family would want to incur the potentially greater tax burden attendant upon income aggregation. It would be administratively impossible to make distinctions on the basis of whether the close relative, or perhaps a friendly stranger, is in fact sufficiently a member of the family to justify inclusion.

\section{Allocation of the Income Tax Burden}

A threshold question in allocating the income tax burden among various units is the relevance of family responsibilities. ${ }^{185}$ The Report is bottomed on taxation in accord with "ability to pay," and it might be anticipated that this standard makes family responsibilities relevant. It is arguable, however, that the choices people make respecting marriage and family size are irrelevant to "ability to pay" and that the general expenses of family responsibilities represent the exercise of "discretionary economic power," rendering them consumption choices. ${ }^{186}$ Thus a bachelor and a married man have merely chosen to spend their money in different ways, and, such being the case, their choices are irrelevant to tax burdens.

The Commission appropriately rejects this "strange" ${ }^{187}$ argument and treats expenses arising from family responsibilities-as well as savings attributable to family groupings-as relevant to tax allocation. $A$ wife and children are not easily regarded as mere consumption choices. And as a matter of social policy, the notion is well-entrenched that taxation should be neutral respecting marriage and children. ${ }^{188}$

184 The adequacy of the credit for support of a close relative would also affect the attitude of the relative and family. See note 46 supra and accompanying text.

185 The idea of making allowance for the fact that persons of equal income may have different responsibilities was of later origin than the income tax itself and is said to have been an "outgrowth of the rising sense of social responsibility and concern for the individual member of the state." P. STrayer, The Taxation of Smale Incomes 44 (1930).

186 Professor Bittker suggests that a "comprehensive tax base" implies that family expenses are indeed irrelevant. Bittker, $A$ "Comprehensive Tax Base" as a Goal of Income Tax Reform, 80 HARv. L. REv. 925, 941 (1967).

187 Thorson, Tax Treatment of Family Income 122; cf. J. Pecharan, FEDERAI TAX POLICY 50 (1966).

188 Oldman \& Temple 602 :

There may be social policies which should be implemented by a government through its tax system, or other quasi-compulsory devices, but decisions as to marriage and children should be left to the widest range of individual choice 
Unless allowances are made for necessary costs arising from marriage and having children, the system cannot be neutral, i.e., there will be a tax cost, a disincentive. ${ }^{189}$

The second question preliminary to allocation is one of general goals. It has been noted that

The formulation of universally applicable principles to guide in the allocation of tax burdens will be a difficult task until a rational theory of progressive taxation is developed and demonstrated. Even then, it is likely that the basic decisions in the application of progressive taxation will continue to involve value judgments of a character that only the electorate can make. ${ }^{190}$

The Commission subscribes to the central objective of equity, vertical and horizontal, as expressed in the standards of "ability to pay" and "discretionary economic power." The Internal Revenue Code's rate structure, meanwhile, is said to reflect a public policy choice made during the depression to redistribute income in order to increase aggregate spending and to attack the economic power of high income groups. ${ }^{191}$ Thus equity, while a principal objective of allocation, is by no means the only possible one. Further, equity is not simply defined. The Commission certainly does an impressive job of solving the definitional problems, with its standard of "discretionary economic power," but it is finally compelled to conclude that, "In a democracy, equity questions ultimately must be resolved in terms of the shared values of the people." 192

that is consistent with the morés and with the economic and sociological needs of a given society.

See Atlas, supra note 127, at 530; Pechman, supra note 103, at 481; Thorson, Tax Treatment of Family Income 129-30.

189 Apart from the consensus for neutrality, it is widely believed that, within limits, the tax treatment of the family cannot have any actual effect on decisions people make about marriage and having children. Oldman \& Temple 602; cf. GRoves, supra note 1 , at 76; P. Taylor, The Economics of Public Finance 402 (1948). See also Britise Royal Commission of the Taxation of Profits and Income, Second Report, $\mathbb{1} 118$, at $36(1954)$ :

[T] he reasons that impel men and women to prefer marriage to more casual associations are many and powerful and . . . the present treatment of the income of married couples for the purpose of tax is not more likely to lead people away from matrimony than tempt them into it.

But cf. SHoup 53 (suggesting that complete exemption of interspousal transfers might stimulate more marriages between persons in different generations); Thorson, Tax Treatment of Family Income 129 (noting that economic factors may be crucial in "family planning" and are of "secondary importance" in other marriage decisions such as those concerning "marital adjustment and divorce").

190 Oldman \& Temple 603.

191 Magill, Federal Income Tax Revision, 1 Tax Revision Conpendium 87-88 (1959).

1923 REPORT 5. 
The Commission's specific yardsticks for allocation, for the most part, seem to be quite reasonable and in accord with the views of economists and tax critics. ${ }^{193}$ One problem, discussed above in the context of undue disincentive to a wife's working, ${ }^{194}$ is the failure to distinguish between one- and two-job families. Failure to draw such a distinction penalizes the working wife and constitutes a departure from the discretionary economic power standard, from equity as defined by the Commission, and from neutral treatment of marriage.

A second problem exists in measuring the degrees of various distinctions. The Commission admits that "judgments" are necessary, ${ }^{195}$ primarily because of the lack of sufficient statistical, comparative data and because of the unreliability of such data as is available. Unquestionably, there is a shortage of information on, for example, the expenses and economies of marriage. ${ }^{196}$ What is available is often met with skepticism. ${ }^{197}$ Complete and reliable data are prerequisites to making the subtle differentiations proposed by the Commission.

Turning to implementation of goals, the Commission proposes separate rate schedules for single persons and married couples. Separate rate schedules are "an especially flexible instrument," and permit "an almost infinite number of compromises." 198 Even though difficult to construct, ${ }^{199}$ their theoretical capacity to differentiate married couples from singles is clear. ${ }^{200}$ A secondary advantage of their use is that by eliminating exemptions, rates can be reduced, with attendant psychological benefits. ${ }^{201}$ Two criticisms can be made of their use. One is that it is difficult to change them later relative to one another, ${ }^{202}$ since, presumably, the basic data would have to be reevaluated. For this reason, Joseph A. Pechman recommends use of a single schedule coupled with adjustments through credits or, prefer-

193 See, e.g., Oldman \& Temple 603-04; Sander, supra note 160, at 20.

184 See text accompanying notes $156-60$ supra.

1953 REPORT 7, 167.

198 See, e.g., Groves, supra note 1, at 105-06; E. MockLER, supra note 72 at 110 ; Pechman, supra note 103, at 479.

107 See, e.g., Fortune, Dec., 1967, at 98 (a section entitled "Shadowy Statistics" ridicules the recent "City Worker's Family Budget" published by the Bureau of Labor Statistics of the United States Department of Labor).

198 Groves, supra note 1, at 77. Accord, Oldman \& Temple 604.

199 Pechman, supra note 103, at 479-80.

200 The idea of separate rate schedules is not new. See Groves, supra note 1 , at 22 (respecting their use internationally); W. VICKREY, AGENDA FOR PROGRESSIVE TAXATION 274-87 (1947); Pechman, supra note 103, at 473-86.

201 Seltzer, supra note 120 , at 510 .

202 Remarks of Joseph A. Pechman, in Canadian Tax Foundation 443. 
ably, varying deductions. The deductions would vary with family income and the number of family members. The adjustments would be designed to accommodate the needed differentiation. ${ }^{203}$ It is also arguable that separate schedules are vulnerable to political forces seeking to make disproportionate adjustments, quite likely to the disadvantage of singles (as happened in the United States with the splitincome rates granted married couples in 1948). While these criticisms may have some validity, it is not clear that a single schedule, or any solution, can solve the problems. The Commission recommends as a means of making short-term adjustments that the tax liability of each individual be multiplied by a factor chosen to increase or decrease each taxpayer's liability by the same percentage amount, ${ }^{204}$ e.g., a ten per cent surcharge on tax liability computed under the rate structure existing at the time.

In addition to dual rate schedules, the Commission recommends use of credits rather than exemptions. The value of a fixed credit does not rise with income; the value of a fixed exemption does, in proportion to the taxpayer's marginal rate. The Commission acknowledges that the expenses of raising children-and by implication other "nondiscretionary expenses"-increase with income, though not as rapidly as the marginal rates of tax increase with income. ${ }^{205}$ The Commission also admits that the proposed credits are not adequate, at least in the case of dependent children. ${ }^{206}$

Thus the Commission moves away from the subtle, precise adjustments it recommends through the dual rate schedules for differentiation of singles and couples. The proposed credits also constitute a departure from the "discretionary economic power" and "equity" goals: in absolute terms the credits are inadequate at all levels, and in relative terms they discriminate in favor of low income families. The impact is hardest on large, low-to-moderate income families for whom the inadequacies of the credits would be compounded (by the number of children) and would be most disruptive to meeting non-discretionary expenses.

To consider alternatives to credits is to raise a whole spectrum of questions relating to the philosophy of progressive taxation, forms and rationales of exemptions, administrability, revenue needs, and so forth. However, given the Commission's goal of taxing on the basis of "discretionary economic power" as measured by sophisticated statistical data, one proposition is particularly worthy of consideration:

203 Id. An extensive study of the forms and rationales of the various credits and exemptions is beyond the scope of this Comment.

2043 REPORT 197.

205 Id. at 17.

200 Id. at 181. 
use of more sophisticated rate schedules based on comprehensive data as to the "discretionary economic power" of various tax units. Size of families, ages of members, total income, various non-discretionary expenses (as those of a working wife), and cost of living differences between geographical regions and types of communities could theoretically be built into the schedules. ${ }^{207}$ If the data could be collectedand admittedly this might be difficult and costly-the Commission's "discretionary economic power" standard could be fully effectuated. To administer the application of such complex criteria, publication of complicated schedules might be possible. Or, in this computerized era, it would seem possible for the government, at reasonable cost, to figure the taxpayer's liability on the basis of specified information reported by the taxpayer at the end of his tax year. However, this technique, in its lack of openness, could well prove unpopular, and thus the degree of sophistication of rate schedules could appropriately be limited to a level found manageable by the average taxpayer. The Commission's view is that more sophisticated rate schedules are not administratively feasible. ${ }^{208}$ This is debatable. ${ }^{209}$

Before considering the resultant burdens under the proposed rate schedules, two warnings are in order. First, the Commission is careful to stress that its allocation is made with a view to other taxes in Canada. For example, it believes that, due to the regressivity of other forms of taxation, the income tax must be progressive merely to achieve a proportional tax system and markedly progressive to obtain a progressive tax system. ${ }^{210}$ Therefore, the schedules cannot be fully evaluated without the context of the entire Canadian system. Second, the Commission has not attempted "to present an 'ideal' set of rates, but rather to achieve a suitable progression within the rate schedules." 211 For this reason, the schedules can be considered only in terms of relative, not absolute, burdens.

The table below indicates the proposed burdens of single persons vis-à-vis married couples with the same total income. It should be noted that, due to the use of credits rather than deductions, "taxable income" is very nearly equal to total income received. ${ }^{212}$

207 Data as a basis for adjustments for the latter two factors can be acquired by studies similar to the recent U.S. BUREAU OF LABor STATISTICS, DEP'T OF LABOR, City Worker's Family Budget For a Moderate Living Standard (1966).

2083 REPORT 179.

209 The Commission merely makes the assertion of infeasibility, without explanation or, apparently, examination.

2103 REPORT 153.

2113 REPORT 197.

212 However, taxable income would not include (for example) amounts paid into qualifying "retirement income plans," id. at 301, or into the child's Account, supra note 53 and accompanying text, or certain gifts in kind, supra note 56. 
Proposed Rates 213

\begin{tabular}{|c|c|c|c|c|}
\hline \multirow[b]{2}{*}{ Taxable Income } & \multicolumn{2}{|c|}{ Tax Liability } & \multicolumn{2}{|c|}{$\begin{array}{l}\text { Reductions of Tax for } \\
\text { Single Man Upon } \\
\text { Marriage to Woman With } \\
\text { No Income }\end{array}$} \\
\hline & Single & Couple & Amount & Percentage \\
\hline Less than $\$ 1,000$ & 0 & 0 & - & - \\
\hline 1,500 & 60 & 0 & $\$ 60$ & $100 \%$ \\
\hline 2,100 & 152 & 0 & 152 & $100 \%$ \\
\hline 3,500 & 405 & 197 & 208 & $51 \%$ \\
\hline 5,000 & 725 & 457 & 268 & $37 \%$ \\
\hline 7,000 & 1,195 & 847 & 348 & $29 \%$ \\
\hline 10,000 & 1,955 & 1,467 & 488 & $25 \%$ \\
\hline 12,000 & 2,515 & 1,907 & 608 & $24 \%$ \\
\hline 15,000 & 3,415 & 2,627 & 788 & $23 \%$ \\
\hline 20,000 & 5,015 & 3,977 & 1,038 & $21 \%$ \\
\hline 25,000 & 6,765 & 5,527 & 1,238 & $18 \%$ \\
\hline 40,000 & 12,515 & 11,077 & 1,438 & $11 \%$ \\
\hline 70,000 & 25,715 & 24,277 & 1,438 & $6 \%$ \\
\hline 100,000 & 40,315 & 38,677 & 1,638 & $4 \%$ \\
\hline 200,000 & 90,315 & 88,677 & 1,638 & $2 \%$ \\
\hline
\end{tabular}

These rates seem to follow the Commission's belief that at low incomes there are diseconomies to marriage and that at high incomes economies are insubstantial. Hence, little account is taken of marriage at the $\$ 25,000$ level and almost none at $\$ 70,000$ and up. ${ }^{214}$

One criticism potentially to be levelled at the schedules is Pechman's contention that, despite their availability to couples with and without children, they take account of expenses for dependent children. $^{215}$ If the schedules are so constructed-and it is unclear whether or not they are-then childless couples receive undue relief. ${ }^{218}$ Also, it should be noticed that the family schedule is quite generous to certain persons who qualify for it, notably surviving, divorced or separated parents with a dependent child, unwed persons with an adopted child, and a unit consisting of two "dependent" children whose parents are deceased or resident outside the country.

213 Adapted from 3 RePORT 170 (table 11-4), 174 (table 11-6), 175 (table 11-7).

214 A $\$ 25,000$ "cut-off" point for economies of marriage was suggested by Professor John W. Ervin in 1947. Ervin, Federal Taxes and the Family, 20 S. CAL. L. REv. 243,256 (1947).

215 Pechman, supra note 202, at 443.

216 The Commission may assume (a) that most couples have dependent children for many of their married years and (b) that it is more advantageous, perhaps for welfare policy purposes, to provide additional relief for children through manipulation of the rates in favor of lower income families than through increasing the dependent child credit, the benefit of which could not be limited to low income families. 


\section{Tax Consequences of Property Transfers Within and Without the Family Unit}

Placing intrafamily property transfers outside the purview of a tax system is a logical, albeit not a compelled, corollary of the choice of the family unit for income tax purposes. For if the family is a social and financial entity, sharing and acting as one, it is logical that transfers of what is, in effect, common property do not rise to the level of taxable events. ${ }^{21 t}$ Beyond this simple logic, however, one must confront the philosophy of transfer taxes, the Commission's recommendation that all transfers by gift or bequest recognized under its proposals be treated as income to the recipient, and the policy of recognizing gains and losses on sales.

There is no clear consensus as to the precise goals of transfer taxation. Certainly one is taxing property once a generation. ${ }^{218}$ Another is reducing the concentration of wealth. ${ }^{219} \mathrm{~A}$ third is taxing windfalls as a special type of "ability to pay" attendant upon a gift or bequest. ${ }^{220}$ And a fourth, sometimes cited, is encouraging inter vivos, gifts, especially to younger generations, by diminishing any incentive to hold property until death. ${ }^{221}$

The Commission proposes that, as a rule, permanent, gratuitous transfers of property be treated as income to the recipient. ${ }^{222}$ Such transfers are depicted as increasing the recipient's economic power in the same way as wages, dividends, interest and property gains and thus as appropriately included in the "comprehensive tax base." ${ }^{223}$

As a rule, gains on the exchange of property are recognized as income under both the Internal Revenue Code ${ }^{224}$ and the Report. ${ }^{225}$ Losses are also recognized under the Commission's proposed "comprehensive tax base." 226 The Code provides in general for recognition of losses on sales, though denying recognition in certain transactions between related taxpayers. ${ }^{227}$

217 Conversely, it is arguable that the appropriateness of intrafamily transfer immunity suggests that the family should be the basic unit for tax purposes.

218 See, e.g., SHOUP 100, 119; G. WHEATCROFT, Estate AND GIFT TAXationA Comparatrve Study 121 (1965); DeWind, The Approaching Crisis in Federal Estate and Gift Taxation, 38 CALIF. L. REV. 79, 110 (1950).

219 See, e.g., Shoup 100-19; Lowndes, $A$ Practical Program for Reforming the Federal Estate Tax, 5 VILL. L. REv. 1, 3 (1959); Rudick, What Alternative to the Estate and Gift Taxes?, 38 CALIF. L. REv. 150, 158 (1950).

220 See, e.g., SHOUP 110, 119.

221 See, e.g., SHOUP 120.

222 The merits of treating gifts and bequests as income are beyond the scope of this Comment. It has been suggested that this proposal will engender more controversy than any other aspect of the Report. Goodman, supra note 4, at 373 .

2233 REPORT 465 . Gifts are exempt, however, to the extent of a $\$ 250$ annual and $\$ 5000$ lifetime exclusion. Id. at 478 .

224 See INT. REv. CODE OF 1954, § 1002.

225 See 3 REPORT 39-42.

2263 REPORT 39-42.

227 INT. REv. CODE of 1954, \$267, disallows deductions on losses from sales or exchanges of property between family members, defined as brothers, sisters, spouse, ancestors and lineal descendants. 


\section{Interspousal Immunity}

Viewed from each of the above perspectives, the case for removal of interspousal transactions from the purview of a tax system is impressive. In terms of the traditional philosophy of transfer taxation, there is only the slightest reason to treat interspousal gifts and bequests as taxable events. Given the economic and social unity of husband and wife, no windfall or special ability to pay arises. And, insofar as a gift or bequest is merely a transfer of title between spouses, not changing the wealth of the unit, it hardly seems to rise to the level of a taxable event justifying imposition of a tax simply to reduce the concentration of wealth. In addition, the policy of taxing property once a generation is not thwarted by immunity, except in the relatively rare situation where husband and wife are of different generations. ${ }^{22 s}$

With respect to encouraging inter vivos giving, especially to younger generations, it may be expected that interspousal immunity will lead to greater fluidity of legal ownership between husband and wife and will in some cases induce the bequest of a greater portion of an estate to the surviving spouse. ${ }^{229}$ These tendencies would delay the passing of property to others, including persons of a younger generation. However, in a transfer tax system imposing graduated tax rates on estates, interspousal immunity does not alter the fact that the splitting of bequests by husband and wife in their respective estates minimizes their total estate tax liability. Under either interspousal immunity or the present Code provisions, notably section 2056's marital deduction, husband and wife can minimize the estate tax in passing property to the children if the first to die leaves half his estate to the children and half to the survivor, who passes it on to the children at death. ${ }^{230}$ In short, interspousal immunity does not necessarily encourage a husband to leave a greater portion of his estate to the wife. On balance, therefore, it is doubtful that interspousal immunity seriously threatens the policy of encouraging inter vivos giving, especially to younger generations.

In the context of the Commission's proposal that gifts and bequests constitute elements of the "comprehensive tax base," interspousal immunity is virtually compelled. Their net economic resources remaining constant, it strains the imagination to conceive of such an interspousal transfer being reported by husband and wife as income. Furthermore, the hardships allegedly brought about by taxing inter-

228 The possibility that husband and wife may be of different generations has led to the suggestion that non-recognition be withdrawn if their ages differ by 20 years or more. Rudick, supra note 219 , at 178.

229 SHOUP 53.

230 See $i d$. at $54-57$. 
spousal transfers ${ }^{231}$ would be compounded by increasing the tax burden, as treating the transfers as income would presumably do. ${ }^{232}$

An analysis of the transfer tax philosophy against a background of treating gifts and bequests as income reveals perhaps less difficulty with interspousal immunity than when such treatment is considered in the traditional transfer tax context. Reduction of the concentration of wealth is facilitated by the expected higher tax burden on recognized transfers and by the incentive to distribute gifts among several recipients (especially persons with low incomes) in order to reduce the total tax burden on the transfers. This renders less significant the rôle of the double tax on a couple's property. On the other hand, this same phenomenon counters the policy of encouraging inter vivos gifts because the greater tax burden on transfers to persons other than the spouse (and children, if they also are entitled to immunity) is an incentive for a husband to parcel out some gifts himself and then to leave property to the wife who can continue to parcel out their property over the years so as to spread out the receipt of income by the desired donees. ${ }^{233}$

The Report's proposal not to recognize sales between spouses is reasonable, given the unity of husband and wife ${ }^{234}$ - together they gain nothing on a sale, nor do they suffer a loss. By comparison, under the present Code's treatment of sales, recognition of gain generally entails a step-up in basis and immunity to a gift tax. In part, lack of recognition is compelled by the Commission's interspousal immunity for gifts and bequests, because even if sales were to be recognized husband and wife could merely cast the transaction in the form of two separate, tax-free gifts. Furthermore, if such sales were recognized, there would still be no gift tax to induce the reporting of a sale, although in some circumstances there might be incentive to report a sale so as to step-up the basis of property for depreciation purposes.

In sum, the case for removing interspousal transfers from the purview of a tax system is strong. As the Commission argues, husband

231 See, e.g., 1 REPORT 18-19; DeWind, supra note 218, at 110.

232 A third framework for analysis of interspousal immunity, and a hybrid of the present Code scheme and the Commission's income treatment, is that of an accessions tax system. This tax, as formulated by Professor William D. Andrews' Proposal in the American Law Institute Federal Estate and Gift Tax Project, Study Draft No. 2, Nov. 14, 1966,

is an excise tax on the transfer of property by gift or on death, but imposed on the recipient rather than the donor or the decedent's estate. Like a transfer tax, the accessions tax would have a graduated rate schedule; but the rate is graduated according to the aggregate taxable accessions of the recipient from all sources, without regard to other property owned or disposed of by the donor or decedent.

Andrews, supra note 139, at 589.

233 This incentive to parcel gifts does not exist under an accessions tax system because gifts are aggregated over the years and a rate schedule based on that total is applied. See $i d$.

234 See Pechman, supra note 202, at 443. 
and wife tend to act as one and to treat the property involved as their property. Horizontal inequities stemming from the order of their deaths, the pattern of gifts between them, and, under the Code, statedetermined property rights are thereby eliminated, ${ }^{235}$ as is the conceptual difficulty and economic harshness of a double tax on their property. Certainly administrative and enforcement problems are eliminated. Families of moderate or little wealth who find it necessary to pass all their property to the surviving spouse regardless of tax considerations also benefit. ${ }^{236}$ In the context of the Commission's choice of the family as the income tax unit and the treatment of gifts and bequests as income, with income defined in terms of the unit, immunity is virtually compelled. In the context of the Code's transfer tax policy, immunity is less compelling because of the substantial loss of revenue that would be entailed. Under the Report this prospect is not as serious because of the anticipated revenues from other sources. Under the Code immunity would require new sources of revenue. ${ }^{237}$

One troubling exception to the Commission's proposal for complete interspousal immunity should be mentioned. The Commission proposes that until a couple has a natural-born child, or until the marriage has lasted for five years, tax-free transfers to the other spouse may be made only in an amount up to one-half the income reported by the unit each year. The Commission believes the limitation is "necessary to reduce tax avoidance through artificially arranged marriages." 238 One commentator has observed:

Personally, I find it too difficult to accept the notion that a man and a woman would enter wedlock on the same grounds that two corporations would amalgamate, in search of a tax-free reorganization. ${ }^{239}$

With respect to the natural-born child limitation, another commentator suggests that it is rather unrealistic to expect that a couple would go to the trouble of adopting a child so as to qualify for tax-free transfers. ${ }^{240}$ Especially in the context of the Report, with recognized gifts and bequests treated as income and the recognition of appreciation on the transferred property as income to the transferor, the limitation seems ill-advised.

235 See text accompanying note 71 supra.

236 See Sнoup 121; Alexander, Federal Estate and Gift Taxation: The Major Issues Presented in the American Law Institute Project, 22 TAX L. REv. 635, 683 (1967).

237 Shoup 53; cf. Alexander, supra note 236, at 683.

2383 REPORT 127.

239 Remarks of Marshall A. Cohen, in Canadian Tax Foundation 257. See Casner, supra note 139, at 556-57 (outlining an American Law Institute Draft Proposal that would grant immunity without limitation to interspousal transfers; in fact, certain transfers would qualify even though transferor and transferee were not married at the time of the transfer, e.g., where the marriage is subsequently annulled). 240 Cohen, supra note 239 , at 258. 
To avoid the inequities of the proposed limitation and still restict the hypothetical, artificially arranged marriage, surely a more reasonable approach can be found. One would be to withdraw the immunity retroactively in cases of "marriage in contemplation of death" and other presumptively mala fide situations where the marriage ends by death or divorce within one year of its creation. For tax purposes, a presumption in these situations could lie against the validity of the marriage, thereby shifting to the taxpayer the burden of proving that the marriage was bona fide. ${ }^{241}$

\section{Immunity for Dependent Children}

The Commission's proposal that intrafamily transfer immunity extend to dependent children is more troublesome. The Commission proposes deferring recognition of parental transfers to children until the child's departure from the family unit, not permanent immunity. With respect to the philosophy of transfer taxation, the merits of immunity for children are about the same as for interspousal transfers. Given the family's unity, gifts and bequests do not amount to windfalls. Further, inter vivos giving to one's children would be encouraged, though perhaps only on a short-term basis, depending upon how the child's withdrawal from the family is treated. If at withdrawal the gifts are taken by the child and a graduated tax applied, be it a transfer or income tax, a bunching effect and higher total tax burden would result. Thus there would be a substantial incentive to make permanent, non-consumed gifts to a child only after his withdrawal in order to spread out the receipts and thereby minimize the tax burden. One result might be a greater tendency for one spouse to leave his estate principally to the other who could then continue to parcel out gifts to once-dependent children. ${ }^{242}$ On the other hand, it can be argued that transfers to children young enough to qualify as dependents are not the kind of socially useful transfers envisioned by the policy, inasmuch as such children are in general unable to make any significant use of the property.

Property is taxed once a generation by providing for its taxation at the child's withdrawal. And the policy against concentration of wealth is likewise implemented by taxing at withdrawal. In fact, this policy is implemented more by taxing at withdrawal after initial immunity than by taxing initially, since under the former approach the value of the gift or bequest at recognition includes appreciation on the property. However, account must be taken of the parcelling phenomenon (which reduces the tax on the property, although presumably it decreases the concentration of wealth) and the fact that

241 This is the basic approach of INT. REv. CoDE of 1954, § 2035.

242 See note 229 supra and accompanying text. 
even if there is no parcelling there is deferment of taxes from the time of the initial transfer to recognition at withdrawal.

As in the case of interspousal transfers, immunity for transfers to dependent children is virtually compelled by the Commission's analysis of the unity of the family coupled with measurement of a unit's income by their aggregate incomes including recognized gifts and bequests.

Assessing the transfer tax philosophy within the context of the Commission's proposal that recognized gifts and bequests give rise to income to the recipient (market value) as well as income to the transferor (to the extent of appreciation), contradictory implications for immunity are encountered. Presumably, the Commission's total tax at withdrawal on property taken by the child will be larger than a transfer tax imposed only on the parents (this of course depends upon the rate schedules involved, exemptions, and, in the context of the Report, income averaging provisions for both parent and withdrawn child). Thus, assuming the Report's treatment of withdrawal gives rise to the greater tax, reduction of concentrations of wealth occurs to a greater extent under immunity coupled with recognition of income (to parents and child) than under immunity coupled with a transfer tax (on the parents alone). Countering this result is the probability that the greater tax burden in the former situation increases the incentive for parents not to make permanent gifts to children until after their withdrawal from the family.

As in the case of interspousal sales, non-recognition of sales between parent and child is sensible on the "entity" analysis and a logical corollary of immunity for gratuitous transfers. However, unlike interspousal sales, parent-child sales, for whatever reason made, must ultimately be reckoned with at the child's withdrawal.

\section{Tax Consequences Surrounding the Child's Withdrawal}

If no transfers of property between parent and dependent child are to be recognized as income, troublesome problems will attend the child's coming of age and withdrawal from the family. Property taken by the child at withdrawal can derive from three sources: his own labors, gratuitous transfers from his parents, or gratuitous transfers from persons ourside the family. Given the child's transient membership in the family, there arises the question of when and how to tax these flows. Products of the departing child's labors may be recognized as they are acquired, when the departing child takes them from the unit, or at both times. Further, his gratuitous receipts from outside the family can be recognized at their transfer to him, at his withdrawal, or at both events. And regardless of when each of the various flows is recognized, under an income or traditional transfer tax approach, the problem arises of measuring their respective amounts. 
The Internal Revenue Code's treatment of these problems turns on the transfer of title to property. A child reports his income and generally receives legal title thereto. Gifts and bequests, whether from parents or outsiders, are taxed to the transferor at the time of transfer, and the child takes title. Thus there is no question of withdrawal in itself being a taxable event: title to property controls, the tax cost for title having been previously paid in the form of the possibility of a tax at the time of acquisition.

The Commission's treatment of the child's withdrawal centers on the child's "Income Adjustment Account" into which a child's earned income (in excess of $\$ 500$ annually) and outside gifts may be deposited. The amounts deposited are in effect excluded from the family income. At the child's withdrawal, all property he takes with him is deemed a gift from the family, subject to $\$ 5,000$ lifetime and $\$ 250$ annual gift exemptions. Coincidentally with withdrawal, he must take the deposited sums from the Account and treat them as income. ${ }^{243}$ Liberal income averaging provisions are available to the withdrawing child in order to mitigate the tax impact of recognizing potentially large sums as income. He may deposit the money in a non-interest bearing Account similar to the child's Account, thereby excluding it from income until removed therefrom. ${ }^{244}$ The professed objective of the child's Account is to avoid a double tax on the eligible amounts, first to the family and then to the child at his departure from the family, by effectuating a pass-through. ${ }^{245}$ However, the Commission severely restricts implementation of the pass-through principle. Unless the deposit is made, the child's earnings and outside gifts, if in fact subsequently taken from the family by the child, are taxed twice, first as income to the family and second as an effective gift from parent to child at his departure.

The child's Account in itself is not without conceptual and practical difficulties. First, non-recognition of deposited sums constitutes a departure from the Commission's "discretionary economic power" standard-the family has the power to decide whether or not to deposit the gift or earnings, giving the family initial control of the property. Second, the deposit can be withdrawn at any time, ${ }^{246}$ making the deposit as much an asset of the family as a savings account (complete with "a modest rate" of interest ${ }^{247}$ ).

A second major difficulty with the Account is one of vertical equity: the Account would be of benefit mainly to middle and upper

243 See note 57 supra and accompanying text.

2443 REPORT 261-81.

2453 REPORT 135-36; see text accompanying note 57 supra.

2463 REPORT 136.

247 Id. at 273. Account deposits would not, however, be assignable. Id. at 260 . Interest would be paid only upon withdrawal, $i d$. at 136 , but it would be possible to withdraw each year an amount equal to the accrued interest. 
income families. Not only can lower income families generally least afford to divert funds from current consumption needs or make significant gifts to children leaving the family unit, but there is also little incentive for them to make deposits since their tax rates are low in any case. Further, children in high income families probably receive the bulk of eligible gifts and earnings through grandfather trusts, better access to higher paying jobs, etc., and would be more inclined to make all eligible deposits in order both to defer taxes on those amounts and to preserve the possibility of their pass-through. ${ }^{248}$ Finally, outside donors would have an incentive to make a gift to the child instead of to the parents in order to permit the family to increase the amount of the child's subsequent immunity by depositing the gift. ${ }^{249}$ If the family later needs the funds, they can always be withdrawn from the Account. And if the family cannot afford to let the child take the deposited funds upon his departure, they can be withdrawn by the child and turned over to the family just prior to his departure. Use of the fund therefore promises to negate much of the effect of inclusion of dependent children for upper income families and to shift additional tax burden onto families unable to take advantage of the Account. ${ }^{250}$

Another serious drawback of the Account is its restrictive effect on investment, appreciation and gifts in kind. Assets deposited cannot be invested or expected to appreciate significantly in value with a potentially deterimental impact on the investment sector of the economy. Gifts in kind cannot be deposited, although "the monetary value thereof" can be. ${ }^{251}$ If a family does not have sufficient cash or borrowing power, the gift in kind will have to be recognized or liquidated and the proceeds deposited, reducing a prospective donor's incentive to give to dependent children.

To circumvent these restrictions, the donor can look to the trust. ${ }^{252}$ There he finds only partial solace. The Commission proposes that transfers in trust, except those for the benefit of members of the settlor's family unit, be taxed initially as income to the trust at the top personal rate of 50 per cent. ${ }^{253}$ There are two exceptions to

248 These families could use the Account in lieu of bank savings.

249 This phenomenon occurs under the Code also, but is limited by the fact that if the parents later want the gift for themselves another transfer tax arises.

250 Upper income families save taxes over the long run if the taxes saved by deposit, plus interest on those taxes, plus interest accrued by the deposit exceed the taxes incurred at the deposit's withdrawal, whether by the family or by the child at his departure, thereby shifting an additional share of the total tax burden of the country to those who do not use the Account. The Commission overtly accepts vertical inequity in the use of the adult's Account. However, that Account does not earn interest and is presented as principally an income averaging measure. Id. at 259-60, 269-73, 278-79.

2513 REPORT 147.

252 The Report deals with trusts at length, at 4 REPORT 149-211, and remarks that "[ $t]$ he trust should be regarded as an instrument to be employed for good personal or business reasons and should not be permitted to be used as a tax-ayoidance device." Id. at 151.

253 Id. at 157. 
this rule. First, where the property is "distributable currently" the beneficiary can elect that the corpus be taxable to himself, in which case the trust pays no initial tax. ${ }^{254}$ Second, if the property is not distributable currently and is to be accumulated for the benefit of a prospective beneficiary who can be identified with reasonable probability, that beneficiary may elect that the trust pay the initial tax at the rate which would be applicable if he received the property directly. ${ }^{255}$ Suppose a grandfather wishes to leave a farm to his grandson in trust to be given over to the grandson when he leaves his family unit. At creation the trust must thus pay a tax based on either the 50 per cent rate or the rate of the grandson's family. ${ }^{256}$ In either case the trust is entitled to pay the tax in installments over five or ten years. ${ }^{257}$ Upon distribution of the farm to the grandson he includes its value in his income, and receives credit for the initial tax. If the initial tax paid by the trust exceeds his tax payable apart from the credit, he is entitled to a refund. ${ }^{258}$

Therefore a prospective donor of a gift in kind to a dependent child is wise to choose a trust in lieu of an immediate gift. This is also true with respect to appreciating property. If a direct gift is made, the family must either recognize its value as income or avoid recognition and effectuate a pass-through to the child by depositing an equivalent sum in the Account. In order to make the deposit the family may have to sell the gift, or borrow on it. If a trust is created, the pass-through can be effectuated without use of the Account. ${ }^{259}$ However, the initial tax on the corpus of the trust may be heavy, depending on the family's other income and the value of the corpus, and may jeopardize both the appreciation and investment prospects of the corpus and, in the case of a gift in kind, the capacity of the trust to pay the tax without selling part of the corpus. Of course, the settlor may be able to endow the trust with sufficient cash assets to cover the initial tax. More likely, he will be inclined to defer disposition of the property until the child has come of age. ${ }^{260}$

$254 I d$.

255 Id. An amount is currently distributable if "it is either distributed in that year or the beneficiary has a right to enforce payment of it in the year." Id. at 153. "An individual would be a prospective beneficiary of an amount if it was indefeasibly vested in him, or if he would be entitled under the trust instrument to receive the amount, if he was living, not later than the death of an income beneficiary who was older than he by at least ten years or on his attaining a specified age not exceeding forty years, or on the later of these events if both conditions are applicable." Id. at 159-60.

$256 \mathrm{See}$ id. at 172 . If the trust pays at the family rate, it does so on the basis of the increment in taxes the family would pay if the corpus were reported as income by the family. Id. at 160 .

257 Id. at 172 .

258 Id. at 161-62.

259 Such a trust's immunity to the double tax may be compared to that of the Account: the assets are not at the family's immediate disposal and are kept "on ice." Also, conceptually, trust assets from non-family settlors are not property taken from the family unit. See 3 REPORT 137.

260 The transfer cannot be deferred beyond the prospective donor's death, however, unless he can pass property to his spouse for subsequent transfer. 
Finally, it is difficult to rationalize the pass-through treatment that the Account also can provide for the child's earned income in excess of $\$ 500$ and outside small gifts. First, a child receives sizable amounts for support and education each year he is a member of the family unit. This is supplied for the most part by his parents; the parents in effect give the deposited sums to the child by allowing him to make the deposit rather than requiring him to contribute to his own support. Second, it is reasonable to assume that in the usual case a child does in fact consume his earnings ${ }^{261}$ and small gifts in the form of self-support in lower income families and leisure and luxuries in upper income families. Thus there is no need to effectuate a passthrough. Third, to the extent that some actual pass-through exists, the proposed $\$ 5,000$ lifetime gift exemption should more than cover it. ${ }^{262}$ A pass-through of small gifts and earned income does not reflect the actual functioning of the family and gives an unfair advantage to upper income families. Only large gifts are likely to be passed through in fact, and only they are likely to be inhibited by failure to get passthrough treatment.

Two proposals for restructuring the Commission's approach to the pass-through should be considered. First, the Account is too restrictive in locking in the deposited funds from investment and appreciation and in being limited to cash deposits. To alleviate the lock-in effect, the government could establish an agency empowered to act as an investment broker for the funds. More practicable, and of more appeal to private enterprise instincts, would be to allow investment in suitably regulated private investment companies to qualify for Account-like treatment. Further, the Account's discrimination against gifts in kind seems unjustified. To effect the pass-through of gifts in kind, a donor under the present proposal can create a trust with the corpus to be distributed upon the child's coming of age. If the trust has sufficient liquid assets with which to pay the initial tax, the passthrough can be effected and the corpus is ultimately taxed only once at the adult beneficiary's rates. However, sufficient liquid assets may not be available and, in any event, there is a substantial disincentive to the prospective donor. To put gifts in kind on a parity with cash gifts, provision should be made for the pass-through, tax-free until the child comes of age, of gifts in kind placed in the hands of suitable (preferably institutional) trustees.

The second major difficulty with the Commission's proposal for implementation of the pass-through principle is the treatment of large gifts to the child that are not deposited in the Account. Deferred recognition of amounts deposited until their withdrawal upon the child's departure from the family is certainly reasonable-the funds 
are put "on ice" until the child comes of age and in a conceptual sense are not received until then. However, it seems unreasonable to impose a double tax on a large gift simply because it is not deposited. Instead, provision should be made for the family to take the gift into the unit, and thus into income; then if the child takes the property from the family unit he should be allowed to do so tax-free, at least, or possibly with a potential refund based on the disparity between his rates and those at which the family initially paid a tax on the property. The latter is the approach used by the Commission for trusts where an initial tax is paid by the trust and the corpus is later distributed; ${ }^{263}$ the former would amount to the exaction of a price for the use of the property and is not essentially alien to the Commission's Account inasmuch as deposits in the Account can be withdrawn at any time and are thus readily available to the family. ${ }^{264}$

Turning briefly to the specific context of the Internal Revenue Code and its transfer taxes, several conclusions appear. First, because a transfer to a child is not treated as income to him or the family and because the transfer tax burden is generally less than an income tax on the transfer would be, immunity for parent-child transfers is not as compelling. Second, since the Code taxes transfers to the transferor, effectuation of the pass-through of large gifts from persons outside the family by the initial transfer tax seems appropriate. Third, the Commission's analysis of the family's unity suggests that parental gifts and bequests to children should be recognized at the child's coming of age, rather than at the earlier time of transfer. Fourth, although the position was rejected by the Commission, it has been argued here ${ }^{265}$ that remnants of earned income and small gifts taken by a child upon leaving the family unit are in fact gifts from the parents. Although probably not large in the aggregate, they should in theory be recognized as such by the Code.

\section{SUMMARY}

The Royal Commission's family unit makes clear the need for reform of the Internal Revenue Code's treatment of the family. Reliance on the economic and social unity of the family, vigorous efforts to fashion an equitable allocation of the income tax burden among various families, and attack on taxation of intrafamily property transfers are all most appropriate.

The Commission has made an impressive start toward defining and implementing the concepts of "progressive taxation" and "equity"

263 See text accompanying note 258 supra.

264 Of course, even if such a pass-through technique is implemented, there would remain a substantial incentive to use the Account instead, thereby deferring taxation on large gifts.

265 See text accompanying note 261 supra. 
through its specific yardsticks and sensitive adjustments to varying individual and family configurations. However, its proposal is not without difficulties. It fails to adjust for the expenses and lost imputed income of working wives, and it unduly penalizes the married student.

Further, the Commission's treatment for property transfer purposes of the child's transient membership in the family, while basically sound, is at times harsh and unduly restrictive. Given the unity of the family, transfer immunity is appropriate if not compelled. It is in turn logical that parental gifts be recognized at the child's departure from the family, and it is likewise appropriate to allow a pass-through of assets acquired by a child while a member of his parents' unit but that ultimately belong to him. The Commission errs, however, in allowing a purported pass-through of small gifts and earned income via the child's Account. More important, pass-through treatment should be accorded large gifts to a child that are not deposited in the Account by taxing the family at receipt of the gift, permitting tax-free withdrawal when the child leaves the unit, and perhaps refunding to the family at that time any tax paid on the gift in excess of that based on the child's rate. And in any event, provision should be made to allow gifts in kind (placed in trust) and large gifts placed in suitably regulated investment companies to be treated like cash gifts placed in the child's Account. 